\title{
Interaction between sperm whales (Physeter macrocephalus) and northern bottlenose whales (Hyperoodon ampullatus) and deep-water trawlers in the Northwest Atlantic
}

\author{
Usua Oyarbide ${ }^{1}$, Laura Feyrer ${ }^{2}$, Jonathan Gordon ${ }^{3}$ \\ ${ }^{1}$ Plentzia Marine Station - Univ Basque Country (PiE-UPV/EHU), Areatza 47, \\ Plentzia-Bizkaia E-48620, Basque Country, Spain \\ e-mail: usualab@gmail.com
}

2Department of Biology, Dalhousie University | 1355 Oxford Street,PO BOX 15000 | Halifax, NS B3H 4R2, Mi'kma'ki, Canada

${ }^{3}$ Sea Mammal Research Unit, Scottish Ocean Institute, University of Saint Andrews, St Andrews, UK, Fife KY16 8LB, UK

\begin{abstract}
Interactions between various cetacean species and fisheries are geographically widespread and diverse. Foraging in association with fishing activities may increase prey encounter rates and possibly increase the quantity and the quality of the food consumed. This paper describes interactions between benthic trawlers, targeting mainly Greenland halibut, and two whale species: sperm whales and northern bottlenose whales, in the eastern Grand Banks of the northwest Atlantic. Whale behaviors were compared during four trawling-related activities: preparing/ shooting the net, towing, hauling and transiting between fishing sites. Sperm whales and bottlenose whales were more likely to be observed during hauling. We observed probable feeding behavior of both species close to the surface at the end of hauling which suggests they are taking fish escaping from the cod end of the net when it is close to the surface. It is not clear whether feeding attempts are made during other phases of the trawling cycle. Ten sperm whales were photo-identified and six of these individuals were resighted on
\end{abstract}


different days. Resights of individuals indicated that sperm whales could follow trawlers through several sets over of distances up to $234 \mathrm{~km}$. While some individuals were observed to move between fishing grounds others remained within one fishing area for some time. By contrast, even though twenty-three bottlenose whales were photo-identified, there were no resights of individual whales. While northern bottlenose whales have been studied quite extensively in some adjacent areas, particularly off Nova Scotia, their behaviour and distribution within the Grand Banks fishing areas has not been well described. No matches were found between northern bottlenose whales in this study and photo-identification catalogues for the Scotian Shelf or the Arctic. Whether and how northern bottlenose whales found in this area are connected to other subpopulations remains unclear.

\section{Introduction}

Interactions between cetacean species and fisheries are geographically widespread and diverse ${ }^{1,2}$. Many fishery interactions are potentially harmful to cetaceans often resulting in mortality due to directed kills by fishers, and/or incidental captures in fishing gear. In addition, cetaceans may be affected if fisheries deplete their prey. Interactions can also have consequences for fishers such as gear damage, depredation of catch from fishing gear and depletion of commercially valuable fish stocks ${ }^{3}$.

With an increasing global human population and a corresponding expanding market for fish, global total landed catches have increased impressively ${ }^{4}$. Fishing in both coastal and pelagic waters is likely to continue to increase, intensifying interactions between fisheries and marine mammal populations through both increased competition for resources and interactions such as entanglement ${ }^{5}$.

Incidental capture and mortality of marine mammals has been reported from a variety of fisheries globally, including trawl ${ }^{6} 7,8$, longline ${ }^{9,10}$, purse seine ${ }^{11,12}$, driftnet ${ }^{13}$, and gillnet 
fisheries ${ }^{8,14,15}$. Some of these interactions represent one of the most significant global threats affecting marine mammal populations ${ }^{16}$.

Cetaceans frequently exploit fisheries as a source of food. Interactions with trawlers have been observed in both odontocetes and mysticetes (Table 1). Feeding in association with fisheries in these ways may provide short term benefits for cetaceans by increasing the quantity and the quality of the food consumed and could reduce time spent searching for prey ${ }^{6,17}$.

Sperm whales and beaked whales have been previously described in the Northwest Atlantic Ocean ${ }^{18-20}$. These species tend to live-in deep-water habitats, which are often far from shore and they perform long, deep dives in search of their squid and fish prey $1,21,22$. This has generally made these animals rather harder to study than more accessible, nearshore cetacean species ${ }^{23}$.

Interaction between sperm whales and longline fisheries have been well-documented in the Southern Ocean and Greenlandic, Norwegian and in Alaskan waters (Table 2) ${ }^{24-26 .}$ Sperm whale depredation of longlines may be a learned behavior initiated when the whales associate fishing operations with feeding opportunities ${ }^{27}$. Such interactions have been well-studied in different areas of the Southern Ocean including in waters off: the Falkland Islands ${ }^{28}$, Southern Chile ${ }^{29}$, Prince Edward Islands ${ }^{30}$, Crozet Islands and Kerguelen ${ }^{31}$ and off Alaska. ${ }^{32}$ Such interactions often include whales following vessels for periods of days ${ }^{31,33}$. They may, occasionally, become entangled in fishing gear. ${ }^{33,34}$

All fishing grounds where depredation has been reported to occur overlap with known natural feeding grounds of sperm whales. The species of fish recorded as taken during sperm whale depredation are often species found in the stomachs of sperm whales taken by whalers operating in the area in earlier years (i.e., predating the establishment of the long line fisheries). Presumably, long lines make it easier for the sperm whale to 
forage by bringing incapacitated prey closer to the surface ${ }^{33,35}$. Depredation by sperm whales from longlines have both economic, environmental fisheries management implications. ${ }^{24,29,36}$

Interactions between sperm whale and trawl fisheries in the northwest Atlantic has been widely reported by fishermen and were described by Karpouzli \& Leaper $^{18}$. While associations with northern bottlenose whales may be more recent, there have been anecdotal reports from fishers in Labrador and the Arctic going back to 2005, as described by Johnson et al. ${ }^{37}$ Some form of foraging advantage seems the most likely explanation for whales to be attracted to fishing operations. These trawl fishery interactions are not thought to lead to direct economic losses for the fishery ${ }^{18}$. However, they result in an increased and undocumented fishery take, they pose a risk of entanglement, and have potential energetic consequences for whales. Additional research is required to assess the ecological impacts of interactions.

The objective of this paper is to describe interactions between two species of deep diving whales, sperm whales and northern bottlenose whales, and benthic trawlers which were principally targeting Greenland halibut, in the northern end of the eastern margin of the Grand Banks of the northwest Atlantic. This area is managed under the provisions of the Northwest Atlantic Fisheries Organization (NAFO).

\section{Material and Methods}

\section{Study area and data collection}

Data on cetacean presence, and behavior during different fishing activities, were collected between the 20th of July and the 13th of September (50 days) of 2007, by UO while working as a NAFO observer on the $51 \mathrm{~m}$ benthic trawler Playa Menduiña Dos. During this time, the vessel operated in four NAFO divisions: $3 \mathrm{~L}, 3 \mathrm{M}, 3 \mathrm{~N}$ and 30 (Figure 1). Cetacean monitoring was carried out on an opportunistic basis, when fishery observer duties allowed. 
Data collected included: location, speed and fishing activity for the Playa Menduiña Dos; cloud cover, sea state, water depth and information on cetacean encounters including species, whale behavior, group size and composition. When possible, photographs of whales were taken during encounters for photoidentification.

Fishermen have vernacular names for their preferred fishing areas. They typically target different species in each area and these areas generally have more relevance than the NAFO blocks (The location of these areas and the NAFO blocks are shown in Figure 1). Data were collected while the Playa Menduiña Dos was engaged in benthic trawling in 8 fishing areas: La Décima, Carson Canyon, Playa Nova, O Pequeno, Flemish Cap, Raíz Cuadrada, Divisoria and El Seco (Figure 1). Fishing effort in each area was decided by the skipper. Trawl tows were typically made parallel to depth contours. The duration of each haul depended on the nature of the sea bottom (depth and relief) and varied between fishing areas.

\section{Behavioral sampling}

An "Observational Unit" for behavioral sampling was a continuous period of consistent observation and data collection. This was typically a period of around 30 min or more of effort, during which one particular type of fishing activity took place. To monitor the occurrence of whales, scan sampling was carried out every ten minutes during each observation unit. Encounters were defined as continuous observation of whales at the surface; an encounter ended when 10 minutes had elapsed with no whales having been observed at the surface.

Vessel activity was allocated to four different phases: (1) preparing and shooting the net, (2) towing, (3) hauling and (4) passaging to other fishing areas. Typically, the time to prepare and shoot the net varied between 45 minutes to 3 hours, depending on the on the area and fishing depth. The average distance between the vessel and the net 
during tows in areas where whale interactions were observed were approximately 2 to $2.3 \mathrm{~km}$.

Six different whale behaviors were scored: (1) swimming parallel to the vessel, (2) following the vessel at a constant speed and near constant distance astern (Figure 2), (3) swimming in an opposite direction from the vessel (normally less than $50 \mathrm{~m}$ ) (4) fluke up, (5) probable feeding and (6) Breaching. For sperm whales the designation "probable feeding behaviour" was inferred from their body positioning underwater (on their side or slowly turning upside down, showing first the dorsal fin, then the blowhole, and finally, their whitish jaw) (Figure 3). For bottlenose whales an assessment of probable feeding behavior was based on observations of repeated short shallow, dives. The whale's beak was seen more often at these times (Figure 4). "Probable feeding behavior" was typical of animals observed astern of the vessel, during the end of hauling when the cod end was close to the vessel's stern and fish escaping the net could be observed. Sea birds were often observed feeding on escaping fish at this time. In particular great shearwaters (Puffinus gravis), which made shallow dives and fulmar (Fulmarus glacialis) which took fish close to the surface. Times of other surface behaviors from whales, such as dives with fluke up, lob-tailing or breaching were also noted. The mean rate of sperm whales 'fluke ups' was calculated by dividing the number of 'flukes up' in an observational unit and divided this by the total time for that unit of observation. The minimum speed of movement for sperm whale was calculated from the distance between two observations of the same photo-identified individual, divided by the time between these sightings.

\section{Photo-identification}

Photographs were taken of the dorsal fin and the surrounding flank area of both species and of the flukes of sperm whales using a digital camera (Canon EOS 30) with a 200 $\mathrm{mm}$ lens when whales were within $\sim 50 \mathrm{~m}$ of the vessel and light and visibility conditions 
allowed. Photo-identification and observations were often hampered by fog and poor visibility.

Photo-identification data collection was more constrained than is typical for studies conducted from dedicated platforms ${ }^{38-43}$. In the current study, geographical coverage was restricted to the area of fishing interest and the whales' position and orientation relative to the boat was also affected by fishing activity. Photographs were taken irrespective of any obvious marking on the individual, and efforts were made to obtain multiple photographs of every individual in each sperm and bottlenose whale group encountered. Individual whales were identified using a variety of unique marks (notches, short and long single linear scrapes, large light patches) on their backs, flanks and dorsal fins, and occasionally on the whale's snouts. In the case of sperm whales, various nicks and marks on the trailing edge of the flukes were also used. Animals were often identified using marks that could only be seen on one side of the body. Where possible photos of both sides were linked but in some cases an identification (ID) made using marks on the right side could be the same as another ID known from marks on the left (and vice versa). The left and right sides of dorsal fins were considered separately for initial identification and analysis, but when identifiable marks spanned both left and right sides (e.g., a distinctive notch), both ID sides were linked by a common identifier. As a result the unique IDs for left and right sides are presented separately as per. ${ }^{43,44}$ The limited duration of this study meant that matches were only attempted over relatively short periods (max. 25 days.). Thus, the persistence of scars and markings were considered stable, reducing the potential for false negatives.

\section{Statistical analysis}

Encounter rates were calculated by dividing the number of encounters (with sperm whales, northern bottlenose whales and both species seen together) by the length of each observation period. Average encounter rates were calculated as the mean encounter rate for observations made in each area or vessel activity state. To assess 
the effect of different fishing areas, vessel activities and the interaction between vessel activity and fishing area on whale presence we modelled relationships between these parameters and whale presence and absence in each observation period using binomial generalized linear models (GLMs) using observation length (hrs) as an offset. Models for sperm whales and northern bottlenose whales were built separately. Observations from fishing areas with $<10$ observation periods and while the vessel was travelling were excluded to avoid model separation due to singularities. All statistics were completed in $\mathrm{R}(2019)^{45}$. Fluke-up rate of sperm for each vessel activity were compared using Kruskal Wallis and Tukey test.

\section{Results}

\section{Vessel activities}

Overall, 200 hours of fishing activity were monitored over 50 days. This included 128 net deployments (14 of which occurred at night). A total of 248 observational units were monitored in several different fishing areas and while travelling between sites (Figure 5A-B). The number of hauls, average duration of each haul, number of observational units, trawl cable length deployed, depth and net's distance from the vessel during towing, and number of days in each fishing area is shown in Table 3. The distance of these fishing areas from two known northern bottlenose whale hot spots, the Gully, south east of Nova Scotia and the Davis Strait off northern Labrador are also shown. Most of the observed hauls were made in Playa Nova (3L), Carson Canyon (3N), 0 Pequeno $(3 \mathrm{~N})$ and La Décima (3L) where the target species was Greenland halibut (Reinhardtius hippoglossoides), El Seco (3N) where the target species were skates (Sp. Raja radiata, Raja senta) and Flemish Cap (3M) where redfish (Sebastes sp) was the target species. Other species such as grenadiers (Macrourus spp) and small number of American plaice (Hippoglossoides platessoides), witch flouder (Glyptocephalus cynoglossus), yellowtail (Limanda ferruginea), white hake (Urophycis tenuis) and cod (Gadus morhua) were also taken. Observations were made during all types of fishing 
activity and the total hours of observation, vessel speed and whale behaviour during each fishing activity is summarised in Table 4.

\section{Whale encounters}

Four cetacean species were observed during daytime observations: sperm whales, northern bottlenose whales, common dolphins and long-finned pilot whales. The most frequently encountered species were sperm whales $(N=129$ encounters across 81 observation periods) and northern bottlenose whales $(\mathrm{N}=86)$. The two species were seen together on 34 occasions. In addition, observations were made during 14 nighttime net hauls which included four encounters with sperm whales and six encounters with northern bottlenose whales. Observation at night, made using the vessel's lights, was reasonably effective when whales were close $(20-30 \mathrm{~m})$ to the boat. Lighting was mainly directed astern to allow the codend to be monitored as the net was hauled to the surface. Whale behavior observed at night was similar to that observed during the day. Other cetaceans observed included common dolphins which often rode the bow the fishing vessel. Long-finned pilot whales were often sighted but were not observed to interact with the boat or fishing gear.

\section{$\underline{\text { Regional differences and whale encounters }}$}

Locations of encounters for each species are shown in Figure 5. Northern bottlenose whales and sperm whales were sighted in fishing areas: La Décima (3L), Playa Nova $(3 \mathrm{~L})$, Carson Canyon $(3 \mathrm{~N})$ and $\mathrm{O}$ Pequeno $(3 \mathrm{~N})$, northern bottlenose whales were also sighted in Raíz Cuadrada (30). These areas are generally on or close to the slope edge, where depths are between 700-1450. Greenland halibut was the target in all areas. Neither species was sighted in Flemish Cap (3M) nor El Seco (3N), where fishery targets were redfish and thorny skates respectively and water depths were much shallower 50-90m (El Seco), and 50-800m (Flemish Cap). 
The mean encounter rates for sperm whales and northern bottlenose whales in each area are summarized in Table 5 and Figure 6C-D. La Décima had the highest mean encounter rate of 1.08 sperm whales per hour of observation and the maximum number of sperm whales during an encounter was observed in Playa Nova $(\mathrm{N}=6)$. Over all sites, the mean number of sperm whales sighted during an encounter was 1.24 (Table 5). For northern bottlenose whales, encounter rate was highest in $O$ Pequeno with 0.78 encounters per hour of observation. The maximum number of northern bottlenose whales in an encounter was 6, in Playa Nova, and the mean number of individuals during all encounters was 1.5 (Table 5).

\section{Whale behaviours and encounters during different vessel activity states}

The behavior of both sperm and northern bottlenose whales' differed with vessel activity, particularly between towing and hauling. During towing most sperm whales were observed swimming parallel to and either abeam or astern of the vessel maintaining a constant speed and distance. The longest sighting of a sperm whale occurred during towing and extended over one hour and 25 minutes as a continuous observation. Possibly feeding behaviour was nor observed during this time. Lobtailing (energetic tail slaps at the surface) and repeated breaching was observed on one occasion during towing. Northern bottlenose whales were typically observed swimming about as far behind the vessel as the net was being towed during the early towing phase, on two occasions repeated breaching was also observed (Figure 6). Northern bottlenose whales disappeared soon after shooting.

During the net hauling phase the boat slows down and the net winches on deck generate an intense noise and vibration through the hull. ${ }^{46}$ At this time, both sperm whales and northern bottlenose whales were often observed astern, swimming quickly towards the vessel. Sperm whales would sometimes fluke. This behavior coincided with the birds feeding on the fish escaping from the net. 
For sperm whales "fluke ups" were observed some five times more often during hauling than during preparing/shooting, and almost 2.5 times more often towards the end of hauling than during towing (Kruskal-Wallis test, Tukey HSD $p<0.05, N=248$ ). The fluking rate per whale (the number of fluke ups per whale per hour) was significantly higher during hauling (0.5 flukes per whale per hour) than during preparing/shooting and towing (0.1 and 0.2 flukes per whale per hour, respectively) (Kruskal-Wallis test, Tukey HSD p<0.05, N=248) (Table 4). Fluke ups are typically performed by sperm whales before steep dives, suggesting that these fluking whales might be diving down to feed on fish escaping the net as it is being hauled in. Probable feeding behavior was only observed at the end of hauling, once the codend was close to the surface coinciding with the birds feeding on escaping fish at shallow depth. Whales did not fluke up at this time.

The mean encounter rates for sperm whales and northern bottlenose whales observed during each vessel activity state is summarized in Table 5 and Figure 6C-D. Encounter rates for both sperm whales and northern bottlenose whales was highest during hauling (Figure 6C). Navigating $(\mathrm{N})$ had the lowest encounter rate for sperm whales, whereas the lowest encounter rates for northern bottlenose whales occurred during towing (Figure 6C).

\section{Modelling whale encounters}

Fishing area and vessel activity state were significant terms in models of NBW and sperm whale presence. GLMs with both variables, but not the interaction between the two, had significantly more support than models with only one or the other term for both species (Table S1). Inspection of the coefficients indicated that relative to Flemish Cap, Decima and Playa Nova were significant areas $(p<0.05)$ for predicting sperm whale presence, similar to northern bottlenose whales which were positively associated with Decima, O Pequeno, and Playa Nova ( $\mathrm{p}$ <.05). Two areas, Raiz Cuadra and Divisoria, where limited observations were recorded (Table 4) were not included in the models as 
there were under 10 hours of observation effort in each and not all fishing activity states were observed. El Seco, where no whales were observed is not significant, despite a large number $(n=26)$ observations. This is likely due to absences inflating estimates and standard error. All vessel activities were significant for predicting whale presence, however unlike the negative association with Towing $(T)$, Hauling $(H)$ and Preparing or Shooting the Net (P/S) were both positively associated with sperm and northern bottlenose whale presence (Table S1). Navigating (N) between areas was not included in GLMs as there was no region associated with the activity.

\section{Photo identification}

Some seven thousand photographs were taken during whale encounters and individuals were identified in these using distinctive markings. Twenty-three northern bottlenose whale identifications were made on 50 separate days based on photographs of the right-side dorsal fins (15 other individuals were identified from left-side dorsal fin). None of the northern bottlenose whales identified were seen on more than one day (Figure 7).

Ten sperm whale identifications were made based on distinctive marks on various parts of their bodies and flukes (Figure 8 and Table 6). Three whales were only identifiable from marks on one side of their bodies, four IDs had marks that could be seen on both sides of their bodies. Two IDs were only from their fluke. Because marks on different parts of the body were used for identification, whales with different ID numbers could be the same individual thus, the ten "identifications" could represent as few as 6 individuals (Table 6).

Some individual whales demonstrated short-term site fidelity. Scratchy was seen on two occasions 11 days apart, with a distance between encounters of only $4 \mathrm{~km}$. Neboa was encountered eight times in a week while fishing in Playa Nova. Although all of these sightings were on the same fishing ground the sighting were spread over more than 100 
km (Table 6, Figure 9). The calculated minimum average swim speed for Neboa over this period was $4.0 \mathrm{~km} / \mathrm{h}$.

Faneca was encountered five times on three consecutive days in Carson Canyon. Sparrow was observed repeatedly with only 5-16 km between encounters, but then seen again on two consecutive days, $58 \mathrm{~km}$ away. Breixo, one of the easiest whales to identify, was observed during five encounters in Playa Nova and during a subsequent encounter in Carson Canyon. The maximum distance between two sightings of Breixo, 20 days apart, was 234 km Between these two encounters in Playa Nova and Carson Canyon, the boat was fishing in different fishing areas (Carson Canyon, El Seco, O Pequeno and Raiz Cuadrada).

Associations between identified individuals were assumed when two whales were sighted during the same unit of observation. There are no indications of strongly preferred associations within this limited dataset and it is notable that Breixo was seen with each of the other identified whales (Figure 10).

\section{Discussion}

There was a clear association between trawling activity and the presence and behavior of both northern bottlenose whales and sperm whales based on standardized observations and statistical analyses in this study. This aligns with observations of whales associating with vessels in the area made by fishermen prior to this study and by dedicated cetacean research in the area in 2016-2017.47 The fishing areas where sperm and northern bottlenose whales were encountered were close to the continental shelf break, in deep waters known to be preferred habitat for both species. ${ }^{48,49}$ Both species were seen most frequently on fishing grounds with water depth between 500 and $1450 \mathrm{~m}$, where the target species for the trawler from which observations were made was Greenland halibut. They were not present in Flemish Cap or El Seco, two areas characterized by shallower waters $(50-800 \mathrm{~m})$ and where the target species are redfish and skates, respectively. 
While we are unclear on their exact foraging strategy, whales increased their association with the vessel and engaged in probable foraging behaviour during hauling. However, fish may escape from the net and become available to predators at any time during the trawl (towing and hauling). In NAFO Regulatory Area the minimum codend mesh size for nets targeting Greenland halibut is $135 \mathrm{~mm}$. Huse et al. (1999) calculated that for nets of this type, retention probability for Greenland halibut with a body length of $42 \mathrm{~cm}$ was 0.5 and retention probability reached 1 when fish had a body length of $\sim 55 \mathrm{~cm}$. Thus, quite sizeable fish can escape and become available as prey. ${ }^{50}$ These fish may be easy to for whales to catch because they are disoriented or disabled and, if they are in open water. This may also make them easier to detect either visually or by echolocation. Further, the prey encounter rate with escapees for a whale following the net may be higher than prey encounter rates for a whale foraging naturally. Finally, when the tow depth of the net reduces during hauling. Whales may benefit by saving time and energy by not having to make long dives to reach foraging depths.

\section{Sperm whales}

Karpouzli \& Leaper's $1997^{18}$ study of interactions of sperm whales and benthic trawlers in the same area as this study showed a pronounced difference in sighting rates with trawling phases. The encounter rates were high during hauling $=0.609$ sightings per hour but they were very low during shooting $=0.022$ and towing $=0.018$. In this study sighting rates during hauling were remarkably similar to those of Karpouzli \& Leaper ${ }^{18}(0.73$ sightings per hour) but also high during shooting (0.78) and towing (0.63). The difference in encounter rates between these studies could suggest a possible increase in associative behavior by whales, indicating they may now increasingly follow the net and boat through all fishing phases.

There are some challenges in drawing conclusions from an opportunistic study such as this in part due to confounding causal factors. It appears that encounters with whales 
may increase during hauling, this could be due to an increase in feeding opportunities because more fish escape at this time, or it may be because the whales are easier to see from the vessel during hauling when the net is closest to the vessel and when range to whales was also significantly lower, than during towing when the net position can be $\sim 2 \mathrm{~km}$ astern of the boat. The fluke up rate was also significantly higher during hauling. This may have made whales easier to sight contributing to the higher sighting rate. This observation also suggests that the rate of diving was higher for whales during the hauling phase, perhaps linked to a higher foraging rate when the net is coming up to the surface.

Six of the photo-identified sperm whales have multiple resights, even though conditions for photo-identification were far from ideal. These resights suggest that individuals may have followed the vessel through different phases of trawling, in some cases over periods of several days. The maximum distance between two sightings of Breixo, 20 days apart, was $234 \mathrm{~km}$. Neboa was seen during 8 hauls on three consecutive days from August $8^{\text {th }}$ to $10^{\text {th }}$. Although all of these sightings were on the same fishing ground the sighting were spread over more than $100 \mathrm{~km}$. We cannot conclude whether or not Brexio followed the vessel or moved between sites on his own accord. However, it seems probable he moved independently as no sperm whales were ever observed on the El Seco fishing ground that where the boat was active between these identifications. The mean vessel speed observed during fishing activities, 3 knots $(5.4 \mathrm{~km} / \mathrm{h})$ for shooting and towing and 0.8 knots $(1.44 \mathrm{~km} / \mathrm{h})$ for hauling, would permit the whales follow the vessel quite easily. The higher minimum speeds for sperm whales between identification locations calculated in this paper, $4.04 \mathrm{~km} / \mathrm{h}$, is very similar to $4.6 \mathrm{~km} / \mathrm{h}$ estimated by Whitehead et al ${ }^{51}$ in Nova Scotia.

Most sightings of sperm whales at higher latitudes are of single individuals, or more rarely small groups of males. However, in a recent study, Kobayashi described long term associations in male sperm whales in the North Pacific. They suggested that these 
may serve to enhance foraging success or provide protection against predators. ${ }^{52}$ Whitehead et al. ${ }^{51}$ reported a mean size for sperm whale "clusters" (whales within 100 $\mathrm{m}$ and coordinating movements) of 1.1 for sperm whales on the Scotian Shelf. In the northeast Atlantic, Weir et al. (2001) observed a mean cluster size of 1.2 during surveys off the west coast of Britain and Ireland ${ }^{53}$. At similar latitudes off the coast of New Zealand in the Southern Hemisphere, coordinated behavior involving multiple male sperm whales has rarely been observed ${ }^{54}$. Thus, the mean cluster size of 1.6 observed in this study, similar to the cluster size of 2.2, observed in the same study area by Karpouzli \& Leaper ${ }^{18}$ and the maximum cluster size of 6 sperm whales, observed during trawling in our study, suggests male sperm whales may aggregate in larger groups in the presence of fishing vessels. ${ }^{18,52}$

\section{Northern bottlenose whales}

In this study we found significant differences between vessel activities and presence of bottlenose whales. Similar to sperm whales, encounter rate was higher during hauling than during towing suggesting northern bottlenose are taking advantage of the opportunity to prey on fish that escape.

A minimum of 23 individuals were photo identified from the right side and 15 from the left-side. However there were no resightings, over the course of this study. This indicates that a large number of bottlenose whales (equivalent to $\sim 16 \%$ of O'Brien and Whitehead's ${ }^{55}$ estimate for the size of the Scotian Shelf population) were involved in trawl interactions. The lack of resights could suggest that individuals are less likely than sperm whales to follow particular vessels between trawling events. It also indicates there may be a high density of northern bottlenose whales in the area that will readily switch to feeding around boats if the opportunity arises.

There have been only a few reports of interactions between northern bottlenose whales and fishing vessels from the NW Atlantic and the arctic. In their review of cetacean trawl 
interactions, Fertl and Leatherwood ${ }^{6}$ identified 15 records (from unpublished data from Canadian Department of Fisheries and Oceans) in which bottlenose whales were reported to have "followed a trawl during haulback." In 2020, Johnson, et a ${ }^{\beta 7}$ identified 15 northern bottlenose whales in groups of 2-6 individuals in our area of study.

Feyrer, et al. reported photographic evidence showing steady rate of entanglement scars gained on the bodies of NBW in the Scotian Shelf catalogue between 1988-2019. These data, the observations reported from this study and reports of NBW interactions with arctic trawl fisheries for Greenland halibut ${ }^{37}$ suggest an unknown level of interactions between NWB with various trawl, longline and gillnet fisheries across the region (summarised in Table 1 of Feyrer, Stewart, et al. 2021) ${ }^{56}$.

Canada currently recognizes two sub-populations of northern bottlenose whales in western north Atlantic. A population of about 143 northern bottlenose whales, listed as endangered by Canada's Species at Risk Act, inhabit the Scotian Shelf off Nova Scotia, with high site fidelity to a large submarine canyon called The Gully ${ }^{20,55}$. Another concentration of northern bottlenose whales can be found in the Davis Strait and northern Labrador; however, the size of this population is unknown ${ }^{57}$. A recent assessment of northern bottlenose whale genetic population structure by Feyrer et al. $(2019)^{58}$ included samples collected near La Decima (i.e. "Newfoundland") and found this region to be an area of mixing between the Scotian Shelf and Labrador-Davis Strait populations. Approximate distances from the fishing areas described here to The Gully and the Davis Strait are shown in Table 3. Our study area (from La Décima) in the north to Raíz Cuadrada in the south) lies mid-way between both populations. A review of catalogues from the Scotian Shelf (1988-2019), Newfoundland (2016-2017) and Labrador-Davis Strait (2003-2018) found no matches between populations or with the individuals in this study. Sighting rates and mean group size calculated in this study suggest that there are a substantial density of animals in this area, mid-way between recognised high density areas in The Gully and the Labrador Sea. Karpouzli \& 
Leaper's $^{18}$ study, which took place from 1996-1997 in the same area, reported the presence of sperm whales but no observations of bottlenose whales. It is possible that over the 10-year period, bottlenose whales have moved into this area and/or have learned to feed in association with trawlers. Northern bottlenose whales in Labrador and Baffin Bay have also been observed interacting with trawl fisheries over the last decade $^{37}$, but how the bottlenose whales encountered in this study are related to these animals remains unclear.

Many interactions between cetaceans and fisheries involve by-catch or entanglement and are detrimental to the species involved ${ }^{2}$. In 2017 a sperm whale was found dead in the wake of a trawler near La Decima during a research cruise conducted by L. Feyrer. In the case of bottlenose whales, fishermen related one instance where a whale was found in the codend of a trawl. However, it was in a high decomposed state and had clearly died somewhat earlier. The interactions between whales and trawl fisheries may also be indirectly harmful as whales that become dependent on feeding in association with vessels may be vulnerable if fishing practices change. In addition, if the fish which are caught by whales after escaping nets would otherwise survive then these interactions will cause the effective catch of the fishery to increase, which may be a concern for managers.

\section{Conclusions}

Our results indicate that in this part of the northwest Atlantic a number of sperm whales and northern bottlenose whales have learnt to associate with trawl fisheries, modifying their foraging behavior to take advantage of novel feeding opportunities. While it is unlikely that the whale interactions described here have appreciable negative effects on catch, and fishermen aboard the vessel at the time did not perceive a conflict, there may be implications for estimating bycatch losses, fish stock assessment and quota calculations. For the whales, associations with fisheries described here have unknown energetic implications. The risks of individuals becoming entangled in gear is unknown. 
Further studies are required to estimate the extent of this behavior across the region and whether the patterns of whales associating with fisheries have changed since 2007 when these observations were made. Based on increased evidence of the occurrence of depredation in the region, understanding of how many whales are involved in trawl associated behavior, the specific foraging techniques employed, the fish species involved and the impact of whales on total catch removals are important questions for management and mitigation. Data for this study was collected opportunistically by the first author while working as a NAFO fisheries observer, demonstrating that there is considerable potential for observers working on vessels to include additional data collection protocols. Increasing requirements for reporting could provide critical but difficult to collect information on interactions between cetaceans and trawlers and support ecosystem-based fisheries management.

\section{Acknowledgements}

This research was carried out as a part of the Marine Environment \& Resources (MER) Joint Master programme (MER Consortium: U Basque Country, U Southampton, U Basque Country). UO was recipient of a mobility scholarship (MEC 2007). We would like to thank the Playa Menduiña Dos' crew and I. Marigómez. An emerging explorer grant from National Geographic and funding from Fisheries and Oceans Canada supported fieldwork conducted by LF in the study area between 2015-2017. 


\section{References}

1. Northridge SP. World review of interactions between marine mammals and fisheries: FAO Rome; 1984.

2. Northridge SP. An updated world review of interactions between marine mammals and fisheries: Food \& Agriculture Org.; 1991.

3. Beddington JR, Beverton R, Lavigne D. Marine mammals and fisheries: London [England]: G. Allen \& Unwin; 1985.

4. FAO. The State of World Fisheries and Aquaculture, 2007; and UN Food and Agriculture Organization. The State of World Fisheries and Aquaculture. 2008.

5. Read AJ, Reynolds J, Perrin W, Reeves R, Montgomery S, Ragen T. Bycatch and depredation. Marine mammal research: conservation beyond crisis. 2005:5-17.

6. Fertl D, Leatherwood S. Cetacean Interactions with Trawls : A Preliminary Review. J Northwest Atl Fish Sci. 1997:219-248.

7. Dans SL, Koen Alonso M, Pedraza SN, Crespo EA. Incidental catch of dolphins in trawling fisheries off Patagonia, Argentina: can populations persist? Ecological Applications. 2003;13(3):754-762.

8. Read AJ, Drinker P, Northridge S. Bycatch of Marine Mammals in U.S. and Global Fisheries. Conservation Biology. 2006;20(1):163-169.

9. Crowder LB, Myers RA. A Comprehensive Study of the Ecological Impacts of the Worldwide Pelagic Longline Industry. Pew Charitable Trusts 2001.

10. Garrison LP, Stokes L. Estimated Bycatch of Marine Mammals and Sea Turtles in the U.S. Atlantic Pelagic Longline Fleet During 2012. NOAA technical memorandum NMFS-SEFSC ; 655: NOAA TECHNICAL MEMORANDUM NMFS-SEFSC-655; 2012:61.

11. Hall MA. An ecological view of the tuna--dolphin problem: impacts and trade-offs. Reviews in Fish Biology and Fisheries. 1998;8(1):1-34.

12. Archer FI, Gerrodette T, Chivers SJ, Jackson A. Annual estimates of the unobserved incidental kill of pantropical spotted dolphin (Stenella attenuata attenuata) calves in the tuna purse-seine fishery of the eastern tropical Pacific. Fishery Bulletin- National Oceanic and Atmospheric Administration 2004;102(2):233-244.

13. Silvani L, Gazo M, Aguilar A. Spanish driftnet fishing and incidental catches in the western Mediterranean. Biological Conservation. 1999;90(1):79-85.

14. Shaughnessy P, Kirkwood R, Cawthorn M, Kemper C, Pemberton D. Pinnipeds, cetaceans and fisheries in Australia: a review of operational interactions. Marine mammals: fisheries, tourism and management issues CSIRO Publishing, Melbourne. 2003:136-152.

15. Du Fresne SP, Grant AR, Norden WS, Pierre JP. Factors affecting cetacean bycatch in a New Zealand trawl fishery. DOC Research \& Development Series. 2007;282:18.

16. Northridge SP, Hofman RJ. Marine Mammal Interaction with Fisheries; 1999.

17. Silva MA, Feio R, Prieto R, Gonçalves JM, Santos RS. Interactions Between Cetaceans and the Tuna Fishery in the Azores. Marine Mammal Science. 2002;18(4):893-901.

18. Karpouzli E, Leaper R. Opportunistic observations of interactions between sperm whales and deep-water trawlers based on sightings from fisheries observers in the northwest Atlantic. Aquatic Conservation: Marine and Freshwater Ecosystems. 2004;14(1):95-103.

19. Gowans S, Dalebout ML, Hooker SK, Whitehead H. Reliability of photographic and molecular techniques for sexing northern bottlenose whales (Hyperoodon ampullatus). Canadian Journal of Zoology. 2000;78(7):1224-1229.

20. Wimmer $\mathrm{T}$, Whitehead $\mathrm{H}$. Movements and distribution of northern bottlenose whales, Hyperoodon ampullatus, on the Scotian Slope and in adjacent waters. Canadian Journal of Zoology. 2004;82(11):1782-1794. 
21. Gaskin DE, Cawthorn MW. Diet and feeding habits of the sperm whale (Physeter Catodon L.) in the cook strait region of New Zealand. New Zealand Journal of Marine and Freshwater Research. 1967;1(2):156-179.

22. Clarke MR, Martins HR, Pascoe P. The diet of sperm whales (Physeter macrocephalus Linnaeus 1758) off the Azores. Philos Trans R Soc Lond B Biol Sci. 1993;339(1287):67-82.

23. Hooker SK, Iverson SJ, Ostrom P, Smith SC. Diet of northern bottlenose whales inferred from fatty-acid and stable-isotope analyses of biopsy samples. Canadian Journal of Zoology. 2001;79(8):1442-1454.

24. Hill P, Laske J, Mitchell E. Results of a Pilot Program to Document Interactions between Sperm Whales and Longline Vessels in Alaska Waters. In: Mem NT ed. U.S. Dep. Commer; 1999:42.

25. Gonzales E, Olavarria C. Interactions between odontocetes and the artisanal fisheries for Patagonian toothfish off Chile. Interactions Between Cetaceans and Longline Fisheries; 2003.

26. Dyb JE. Fisheries depredation experience of the Norwegian longline fleet. Proceedings from the symposium: Fisheries Depredation by Killer and Sperm Whales, Behavioural Insight, Behavioural Solutions; 2006.

27. Schakner ZA, Lunsford C, Straley J, Eguchi T, Mesnick SL. Using Models of Social Transmission to Examine the Spread of Longline Depredation Behavior among Sperm Whales in the Gulf of Alaska. PLOS ONE. 2014;9(10):e109079.

28. Nolan CP, Liddle GM, Elliot J. Interactions between killer whales (Orcinus orca) and sperm whales (Physeter macrocephalus) with a longline fishing vessel. Marine Mammal Science. 2000;16(3):658-664.

29. Hucke-Gaete R, Moreno C, Arata J. Operational Interactions between Marine Mammals and the Patagonian Toothfish (Dissostichus eleginoides) Fishery off Southern Chile. CCAMLR Science. 2004;11:127-140.

30. Kock K-H. The direct influence of fishing and fishery-related activities on non-target species in the Southern Ocean with particular emphasis on longline fishing and its impact on albatrosses and petrels - a review. Reviews in Fish Biology and Fisheries. 2001;11(1):31-56.

31. Capdeville D. Interaction of marine mammals with the longline fishery around the Kerguelen Islands (division 58.5.1) during the 1995/96 cruise. Ccamlr Science. 1997;4:171-174.

32. Straley JM, Schorr GS, Thode AM, et al. Depredating sperm whales in the Gulf of Alaska: local habitat use and long distance movements across putative population boundaries. 2014.

33. Ashford JR, Rubilar PS, Martin AR. Interactions between cetaceans and longline fishery operations around South Georgia. Marine Mammal Science. 1996;12(3):452-457.

34. Richard G, Bonnel J, Tixier P, Arnould JPY, Janc A, Guinet C. Evidence of deep-sea interactions between toothed whales and longlines. Ambio. 2020;49(1):173-186.

35. Okutani T, Nemotot T. Squids as the food of sperm whale in the Bering Sea and Alaskan Gulf. Sci Rep Whales Res Inst. 1964;18:111-121.

36. Zollett EA, Read AJ. Depredation of catch by bottlenose dolphins (Tursiops truncatus) in the Florida king mackerel (Scomberomorus cavalla) troll fishery. Fishery Bulletin. 2006;104(3):343-349.

37. Johnson KF, Hussey NE, Ferguson SH. Observation of marine mammal and bird interactions focused around a commercial fishing vessel in central Baffin Bay, Nunavut. Arctic Science. 2020:1-8.

38. Whitehead H, Gordon J. Methods of obtaining data for assessing and modelling sperm whale populations which do not depend on catches. Reports of the International Whaling Commission (special issue). 1986;8:149-166.

39. Arnbom TA. Individual photographic identification : a key to the social organization of sperm whales. Vol. Master Thesis. Memorial University of Newfoundland: Memorial University of Newfoundland; 1987:92.

40. Whitehead H. Mark-Recapture Estimates with Emigration and Re-Immigration. Biometrics. 1990;46(2):473-479. 
41. Hammond $\mathrm{P}$, Sears $\mathrm{R}$, Berube $\mathrm{M}$. A note on problems in estimating the number of blue whales in the Gulf of St Lawrence from photo-identification data. Rep int Whal Commn. 1990:141-142.

42. Childerhouse SJ, Dawson SM, Slooten E. Abundance and seasonal residence of sperm whales at Kaikoura, New Zealand. Canadian Journal of Zoology. 1995;73(4):723-731.

43. Gowans S, Whitehead H. Photographic identification of northern bottlenose whales (Hyperoodon ampullatus): Sources of heterogeneity from natural marks. Marine Mammal Science. 2001;17(1):76-93.

44. Feyrer LJ. A Guide to Northern Bottlenose Whale Photo ID. Dalhousie University. 2020(Version 3.0):1-50.

45. Team RC. R: A language and environment for statistical computing. $R$ Foundation for Statistical Computing, Vienna, Austria. 2018.

46. Daly $E$, White $M$. Bottom trawling noise: Are fishing vessels polluting to deeper acoustic habitats? Marine Pollution Bulletin. 2021;162:111877.

47. Marotte E. Management solutions for an at-risk population of northern bottlenose whales (Hyperoodon ampullatus) in the international waters of the Sackville Spur Dalhousie University. 2017.

48. Gomez C, Lawson J, Kouwenberg AL, et al. Predicted distribution of whales at risk: identifying priority areas to enhance cetacean monitoring in the Northwest Atlantic Ocean. Endangered Species Research. 2017;32:437-458.

49. Whitehead H, Wimmer T. Heterogeneity and the mark-recapture assessment of the Scotian Shelf population of northern bottlenose whales (Hyperoodon ampullatus). Canadian Journal of Fisheries and Aquatic Sciences. 2005;62(11):2573-2585.

50. Huse I, C. Gundersen A, H. Nedreaas K. Relative selectivity of Greenland halibut (Reinhardtius hippoglossoides, Walbaum) by trawls, longlines and gillnets. Fisheries Research. 1999;44(1):75-93.

51. Whitehead H, Brennan S, Grover D. Distribution and behaviour of male sperm whales on the Scotian Shelf, Canada. Canadian Journal of Zoology. 1992;70(5):912-918.

52. Kobayashi $\mathrm{H}$, Whitehead $\mathrm{H}$, Amano $\mathrm{M}$. Long-term associations among male sperm whales (Physeter macrocephalus). PLOS ONE. 2020;15(12):e0244204.

53. Weir CR, Pollock C, Cronin C, Taylor S. Cetaceans of the Atlantic Frontier, north and west of Scotland. Continental Shelf Research. 2001;21(8):1047-1071.

54. Gordon J, Leaper R, Hartley FG, Chappell O. Effects of whale-watching vessels on the surface and underwater acoustic behaviour of sperm whales off Kaikoura, New Zealand. Science \& Research Series. 1992;52.

55. Brien KO, Whitehead H. Population analysis of Endangered northern bottlenose whales on the Scotian Shelf seven years after the establishment of a Marine Protected Area. Endangered Species Research. 2013;21(3):273-284.

56. Feyrer LJ, Stewart M, Yeung J, Soulier C, Whitehead H. Origin and persistence of markings in a long-term photo-identification dataset reveal the threat of entanglement for endangered northern bottlenose whales (Hyperoodon ampullatus). Front Mar Sci. 2021.

57. Whitehead H, Faucher A, Gowans S, McCarrey S. Status of the northern bottlenose whale, Hyperoodon ampullatus, in the Gully, Nova Scotia. Canadian field-naturalist Ottawa ON. 1997;111(2):287-292.

58. Feyrer LJ, Bentzen P, Whitehead H, Paterson IG, Einfeldt A. Evolutionary impacts differ between two exploited populations of northern bottlenose whale (Hyperoodon ampullatus). Ecology and Evolution. 2019;9(23):13567-13584.

59. Chilvers BL, Corkeron PJ. Trawling and bottlenose dolphins' social structure. Proceedings Biological sciences / The Royal Society. 2001;268(1479):1901-1905.

60. Kovacs CJ, Perrtree RM, Cox TM. Social Differentiation in Common Bottlenose Dolphins (Tursiops truncatus) that Engage in Human-Related Foraging Behaviors. PLOS ONE. 2017;12(2):e0170151. 
61. Leatherwood S, McDonald D, Baird R, Scott M. The false killer whale, Pseudorca crassidens: a synopsis of knowledge. San Diego: Oceans Unlimited Tech. Rep. 198 p.+ Appendix 1 (114 p.); 1989.

62. Barros N, Jefferson TA, Parsons ECM. Feeding Habits of Indo-Pacific Humpback Dolphins (Sousa

chinensis) Stranded in Hong Kong. Aquatic Mammals. 2004;30(1):179-188.

63. Morizur Y, Berrow SD, Tregenza NJC, Couperus AS, Pouvreau S. Incidental catches of marine-mammals in pelagic trawl fisheries of the northeast Atlantic. Fisheries Research. 1999;41(3):297-307.

64. Lien J. Entrapments of large cetaceans in passive inshore fishing gear in Newfoundland and Labrador (1979-1990). Reports of the International Whaling Commission. 1994(15):149.

65. Couperus A. Interactions between Dutch midwater trawl and Atlantic white-sided dolphins (Lagenorhynchus acutus) southwest of Ireland. Northw AtI Fish Sci,. 1997;2:209-218.

66. Purves MG, Agnew DJ, Balguerías E, Moreno C, Watkins B. Killer Whale (Orcinus orca) and Sperm Whale (Physeter macrocephalus) Interactions with Longline Vessels in the Patagonian Toothfish Fishery at South Georgia, South Atlantic. CCAMLR Science;11:111-126.

67. Bearzi G, Reeves RR, Notarbartolo-Di-Sciara G, et al. Ecology, status and conservation of short-beaked common dolphins Delphinus delphis in the Mediterranean Sea. Mammal Review. 2003;33(3-4):224-252.

68. Roche C, Guinet C, Gasco N, Duhamel G. Marine mammals and demersal longline fishery interactions in Crozet and Kerguelen Exclusive Economic Zones: An assessment of depredation levels. Ccamlr Science. 2007;14:67-82.

69. Söffker M, Trathan P, Clark J, Collins MA, Belchier M, Scott R. The Impact of Predation by Marine Mammals on Patagonian Toothfish Longline Fisheries. PLOS ONE. 2015;10(3):e0118113. 


\section{Tables}

Table 1. Reports of cetaceans feeding in association with trawls

\begin{tabular}{|c|c|c|c|c|}
\hline Suborder & Species & Scientific name & Location & Reference \\
\hline \multirow[t]{16}{*}{ Odontoceti } & $\begin{array}{c}\text { Bottlenose } \\
\text { dolphin }\end{array}$ & $\begin{array}{c}\text { Tursiops } \\
\text { truncatus }\end{array}$ & Gulf of Mexico, Indian Ocean & 6,59 \\
\hline & $\begin{array}{c}\text { Indo-Pacific } \\
\text { bottlenose } \\
\text { dolphin }\end{array}$ & $\begin{array}{l}\text { Tursiops } \\
\text { aduncus }\end{array}$ & Indian Ocean & 59,60 \\
\hline & $\begin{array}{c}\text { Rough-toothed } \\
\text { dolphins }\end{array}$ & $\begin{array}{c}\text { Steno } \\
\text { bredanencsis }\end{array}$ & Indian Ocean & 6 \\
\hline & $\begin{array}{c}\text { False killer } \\
\text { whale }\end{array}$ & $\begin{array}{l}\text { Pseudorca } \\
\text { crassidens }\end{array}$ & North Pacific Ocean & 61 \\
\hline & $\begin{array}{l}\text { Atlantic } \\
\text { spotted } \\
\text { dolphin } \\
\end{array}$ & Stenella frontalis & Gulf of Mexico & 6 \\
\hline & Tucuxi & Sotalia fluviatilis & South Atlantic & 62 \\
\hline & $\begin{array}{l}\text { Long- finned } \\
\text { Pilot whale }\end{array}$ & $\begin{array}{c}\text { Globicephala } \\
\text { melas }\end{array}$ & North Atlantic & 63,64 \\
\hline & $\begin{array}{c}\text { Nothern } \\
\text { bottlenose } \\
\text { whale } \\
\end{array}$ & $\begin{array}{l}\text { Hyperoodon } \\
\text { ampullatus }\end{array}$ & North Atlantic & 6 \\
\hline & $\begin{array}{c}\text { Atlantic } \\
\text { white-sided } \\
\text { dolphin } \\
\end{array}$ & $\begin{array}{l}\text { Lagenorhincus } \\
\text { acutus }\end{array}$ & North Atlantic & 65 \\
\hline & Killer whale & Orcinus orca & North and South Atlantic & $28,29,66$ \\
\hline & Sperm whale & $\begin{array}{c}\text { Physeter } \\
\text { macrocephalus }\end{array}$ & $\begin{array}{c}\text { North Atlantic, Southern Ocean, } \\
\text { Greenlandic, Norwegian and Alaskan waters }\end{array}$ & $18,24,28-31,66$ \\
\hline & $\begin{array}{l}\text { Common } \\
\text { dolphin }\end{array}$ & $\begin{array}{c}\text { Delphinus } \\
\text { delphis }\end{array}$ & Mediterranean Sea & 67 \\
\hline & $\begin{array}{l}\text { Stripped } \\
\text { dolphin }\end{array}$ & $\begin{array}{c}\text { Stenella } \\
\text { coeruleoalba }\end{array}$ & Mediterranean Sea & 67 \\
\hline & $\begin{array}{l}\text { Spinner } \\
\text { Dolphin }\end{array}$ & $\begin{array}{c}\text { Stenella } \\
\text { longirostris }\end{array}$ & Indian Ocean & 6 \\
\hline & $\begin{array}{c}\text { Indopacific } \\
\text { hump-backed } \\
\text { dolphin } \\
\end{array}$ & Sousa chinensis & Indian Ocean & 62 \\
\hline & $\begin{array}{c}\text { Common } \\
\text { dolphin }\end{array}$ & $\begin{array}{l}\text { Delphinus } \\
\text { delphis }\end{array}$ & Indian Ocean & 59 \\
\hline \multirow[t]{2}{*}{ Mistyceti } & Fin whale & $\begin{array}{l}\text { Balaenoptera } \\
\text { physalus }\end{array}$ & North Atlantic & 6 \\
\hline & Minle whale & $\begin{array}{l}\text { Balaenoptera } \\
\text { acutorostrata }\end{array}$ & North Atlantic & 6 \\
\hline
\end{tabular}


bioRxiv preprint doi: https://doi.org/10.1101/2021.10.25.464263. this version posted October 26, 2021. The copyright holder for this preprint (which was not certified by peer review) is the author/funder, who has granted bioRxiv a license to display the preprint in perpetuity. It is made available under aCC-BY 4.0 International license.

Table 2. Summary of global sperm whale (Physeter macrocephalus) depredation

\begin{tabular}{|c|c|c|c|c|}
\hline Ocean & Place & Target Species & $\begin{array}{c}\text { Fishing } \\
\text { technique }\end{array}$ & Reference \\
\hline $\begin{array}{c}\text { South Atlantic } \\
\text { Ocean }\end{array}$ & Falkland Islands & Patagonian toothfish & Longline & 28 \\
\hline Southern Ocean & Kerguelen & Patagonian toothfish & Longline & 31 \\
\hline Southern Ocean & Crozet Islands & Patagonian toothfish & Longline & ${ }^{38}$ \\
\hline $\begin{array}{c}\text { Southern Ocean } \\
\text { Prince Edward } \\
\text { Islands }\end{array}$ & Patagonian toothfish & Longline & ${ }^{29}$ \\
\hline Southern Ocean & South Georgia & Patagonian toothfish & Longline & 25 \\
\hline $\begin{array}{c}\text { South Pacific } \\
\text { Ocean }\end{array}$ & Chile & Patagonian toothfish & Artisan & 29 \\
\hline $\begin{array}{c}\text { South Pacific } \\
\text { Ocean }\end{array}$ & Chile & Patagonian toothfish & Longline & 24 \\
\hline $\begin{array}{c}\text { North Pacific } \\
\text { Ocean }\end{array}$ & Alaska & Sablefish,Halibut Grenadiers & Longline & 26 \\
\hline $\begin{array}{c}\text { North Atlantic } \\
\text { Ocean }\end{array}$ & Greenland & Greenland halibut Atlantic halibut \\
Atlantic cod & Longline & \\
\hline North East Atlantic & Norway & Greenland Halibut & Longline & http://arcticswirl.blogspot.co.uk/ \\
\hline $\begin{array}{c}\text { Northwest Atlantic } \\
\text { Ocean }\end{array}$ & East Canada & Greenland halibut & $\begin{array}{c}\text { Benthic } \\
\text { trawling }\end{array}$ \\
\hline
\end{tabular}


Table 3. Target species and summary information for each fishing area. Predicted presence is based on binomial GLM probability of presence, areas with low numbers of observations $(\mathrm{N} \leq 10)$ are not included.

\begin{tabular}{|c|c|c|c|c|c|c|c|c|c|c|c|c|}
\hline NAFO & Fishing Area & Target Species & $\begin{array}{c}\text { Depth } \\
\text { Range }(\mathrm{m})\end{array}$ & $\begin{array}{l}\text { Distance to } \\
\text { the Gully } \\
(\mathrm{Km})\end{array}$ & $\begin{array}{l}\text { Distance to } \\
\text { Sea of } \\
\text { Labrador } \\
(\mathrm{Km})\end{array}$ & $\begin{array}{l}\text { Tow Cable } \\
\text { lengths }(m)\end{array}$ & $\begin{array}{c}\text { Mean } \\
\text { distance } \\
\text { net to boat } \\
\text { during } \\
\text { towing }(\mathrm{m}) \\
\end{array}$ & Mean haul duration (h) & $\begin{array}{l}\text { Average } \\
\text { Haul } \\
\text { Length } \\
(\mathrm{km})\end{array}$ & $\begin{array}{c}\text { Hauls } \\
\text { observed } \\
\text { (N) }\end{array}$ & $\begin{array}{l}\text { Observation } \\
\text { Periods } \\
\text { Total } \\
\text { (n) }\end{array}$ & $\begin{array}{c}\text { Total } \\
\text { Observation } \\
\text { Time } \\
\text { (h) }\end{array}$ \\
\hline \multirow[t]{2}{*}{$3 \mathrm{~L}$} & Décima & \multirow{2}{*}{$\begin{array}{c}\text { Greenland } \\
\text { halibut }\end{array}$} & $750-1400$ & 970 & 1000 & $2500-2700$ & $2377 \pm 127$ & $7.3 \pm 1.2$ & 36 & 10 & 16 & 12.9 \\
\hline & Playa Nova & & $750-1450$ & 1044 & 1300 & $2200-2700$ & $2264 \pm 186$ & $10.6 \pm 1.9$ & 59 & 48 & 101 & 90 \\
\hline \multirow[t]{3}{*}{$3 \mathbf{N}$} & O Pequeno & \multirow{2}{*}{$\begin{array}{c}\text { Greenland } \\
\text { halibut }\end{array}$} & $500-1450$ & 800 & 1647 & $1700-2800$ & $2301 \pm 332$ & $55.4 \pm 1.3$ & 46 & 21 & 39 & 31.2 \\
\hline & $\begin{array}{l}\text { Carson } \\
\text { Canyon }\end{array}$ & & $700-1300$ & 1060 & 1400 & $2000-2400$ & $1957 \pm 118$ & $8.4 \pm 2.4$ & 25 & 12 & 27 & 24.9 \\
\hline & El Seco & $\begin{array}{l}\text { Thorny } \\
\text { skate }\end{array}$ & $50-90$ & 1137 & 1290 & 340 & $331 \pm 4$ & $4.9 \pm 1.6$ & $\mathrm{~N} / \mathrm{A}$ & 25 & 26 & 21 \\
\hline \multirow[t]{2}{*}{30} & Raíz Cuadrada & $\begin{array}{l}\text { Greenland } \\
\text { halibut }\end{array}$ & $900-1100$ & 331 & 1500 & 2500 & $2281 \pm 60$ & $11.6 \pm 4.9$ & 32 & 2 & 2 & 10 \\
\hline & Divisoria & Redfish & 550 & 1382 & 1700 & 600 & 1775 & 11 & & 1 & 4 & 0.6 \\
\hline $3 M$ & Flemish Cap & Redfish & $50-800$ & 1144 & 1255 & 850 & $797 \pm 11$ & $4.5 \pm 1.9$ & 18 & 9 & 15 & 11.6 \\
\hline
\end{tabular}


Table 4. Fishing vessel activities and summary information for encounters with sperm whales and northern bottlenose whales. Encounter rates are calculated per observation period and averaged for all observations in a vessel activity state, calculated with a $95 \%$ bootstrap confidence interval.

\begin{tabular}{|c|c|c|c|c|c|}
\hline & $\begin{array}{l}\text { Preparing/ } \\
\text { Shooting }\end{array}$ & Towing & Hauling & Navigating & Summary Total \\
\hline Mean speed (knots) $\pm S D$ & $5.37 \pm 2.57$ & $3.04 \pm 0.52$ & $1.44 \pm 0.89$ & $6.78 \pm 2.57$ & - \\
\hline Observational units & 68 & 82 & 82 & 16 & 248 \\
\hline Total time observed (h) & 48.9 & 85.0 & 51.6 & 14.3 & 199.8 \\
\hline No. encounters SW & 24 & 24 & 44 & 2 & 129 \\
\hline No. encounters NBW & 20 & 15 & 46 & 5 & 86 \\
\hline $\begin{array}{l}\text { No. encounters both species } \\
\text { (included in species total) }\end{array}$ & 10 & 2 & 21 & 1 & 34 \\
\hline Sperm whale encounter rate \pm SE $\left(h^{-1}\right)$ & $0.53 \pm 0.11$ & $0.35 \pm 0.07$ & $0.67 \pm 0.09$ & $0.19 \pm 0.13$ & - \\
\hline NBW encounter rate $\left(\mathrm{h}^{-1}\right)$ & $0.45 \pm 0.10$ & $0.22 \pm 0.08$ & $0.73 \pm 0.11$ & $0.40 \pm 0.16$ & - \\
\hline Total no. of flukes & 4 & 14 & 26 & 0 & 44 \\
\hline Average fluke rate $\left(h^{-1)}\right.$ & 0.1 & 0.2 & 0.5 & 0 & - \\
\hline Max no. SW observed in an encounter & 6 & 5 & 5 & 1 & - \\
\hline Max no. NBW observed in an encounter & 5 & 9 & 5 & 3 & - \\
\hline Mean no. SW observed per encounter \pm SD & $1.8 \pm 1.1$ & $1.2 \pm 0.4$ & $1.8 \pm 0.9$ & 1 & - \\
\hline Mean no. NBW observed per encounter \pm SD & $2.7 \pm 1.1$ & $2.0 \pm 1.9$ & $2.8 \pm 1.2$ & $2.3 \pm 0.5$ & - \\
\hline
\end{tabular}


Table 5. Fishing areas with summary information for encounters with sperm whales and northern bottlenose whales. Encounter rates are calculated per observation period and averaged for all observations in an area, calculated with a $95 \%$ bootstrap confidence interval. Differences in summary totals due to time spent navigating between areas and values for all vessel states are included in Table 5.

\begin{tabular}{|c|c|c|c|c|c|c|c|c|c|c|}
\hline & $\begin{array}{l}\text { Carson } \\
\text { Canyon }\end{array}$ & Decima & $\begin{array}{l}\text { Raiz } \\
\text { Cuadrada }\end{array}$ & $\begin{array}{l}\text { O } \\
\text { Pequeno }\end{array}$ & $\begin{array}{l}\text { Playa } \\
\text { Nova }\end{array}$ & Divisoria & EI Seco & $\begin{array}{l}\text { Flemish } \\
\text { Cap }\end{array}$ & $\begin{array}{c}\text { Mean } \\
(95 \% \mathrm{Cl})\end{array}$ & $\begin{array}{c}\text { Summary } \\
\text { Total }\end{array}$ \\
\hline Total time observed (h) & 23.2 & 12.3 & 1.75 & 28.8 & 82.6 & 7.6 & 18.2 & 10.7 & 22.2 & 185.2 \\
\hline Observational units & 27 & 16 & 2 & 39 & 101 & 5 & 26 & 15 & 28.75 & 213 \\
\hline Number encounters SW & 22 & 19 & 6 & 13 & 85 & 0 & 0 & 1 & & 148 \\
\hline Number encounters NBW & 2 & 11 & 1 & 22 & 59 & 2 & 0 & 1 & & 98 \\
\hline $\begin{array}{l}\text { Number encounters both } \\
\text { species at same time } \\
\text { (included in species total) }\end{array}$ & 2 & 4 & 1 & 6 & 22 & 0 & 0 & 1 & & 36 \\
\hline $\begin{array}{l}\text { Sperm whale encounter rate } \\
\qquad\left(h^{-1}\right) \pm S E\end{array}$ & $\begin{array}{c}0.42 \pm \\
0.12\end{array}$ & $1.08 \pm 0.18$ & $\begin{array}{l}1.57 \pm \\
0.82^{*}\end{array}$ & $0.58 \pm 0.18$ & $\begin{array}{c}0.63 \pm \\
0.20\end{array}$ & $0.0 \pm 0$ & 0.0 & $\begin{array}{l}0.10 \pm \\
0.10^{*}\end{array}$ & & - \\
\hline NBW encounter rate $\left(h^{-1}\right) \pm S E$ & $\begin{array}{l}0.10 \pm \\
0.07\end{array}$ & $0.63 \pm 0.20$ & $\begin{array}{l}0.37 \pm \\
0.38^{*}\end{array}$ & $0.78 \pm 0.21$ & $\begin{array}{l}0.58 \pm \\
0.09\end{array}$ & $0.30 \pm 0.30$ & 0.0 & $\begin{array}{c}0.10 \pm^{*} \\
0.10\end{array}$ & & - \\
\hline $\begin{array}{l}\text { Max number SW observed in } \\
\text { an encounter }\end{array}$ & 2 & 1 & 3 & 2 & 6 & - & - & - & 2.8 & - \\
\hline $\begin{array}{c}\text { Max number BW observed in } \\
\text { an encounter }\end{array}$ & 5 & 9 & 2 & 5 & 5 & 1 & - & - & 4.5 & - \\
\hline $\begin{array}{l}\text { Mean number SW observed } \\
\text { per encounter }\end{array}$ & $1.4 \pm 0.5$ & $2.1 \pm 1.1$ & $1.5 \pm 0.8$ & $1.1 \pm 0.3$ & $1.6 \pm 0.9$ & - & - & - & $1.5 \pm 0.4$ & - \\
\hline $\begin{array}{l}\text { Mean number BW observed } \\
\text { per encounter }\end{array}$ & $3 \pm 0$ & $2.5 \pm 2.3$ & $3 \pm 0$ & $2.5 \pm 1$ & $2.7 \pm 1.2$ & 1 & - & - & $2.3 \pm 0.7$ & - \\
\hline
\end{tabular}

*Note there was only one encounter in these fishing areas 
Table 6. Summary of sperm whale photo id data, showing date, haul number, time, fishing area, vessel activity and speed of each encounter. (H) Hauling (P/S) Preparing/Shooting (T) Towing

\begin{tabular}{|c|c|c|c|c|c|c|c|c|c|c|c|}
\hline Name & ID features & Date & $\begin{array}{l}\text { Haul } \\
\text { Number }\end{array}$ & Time & $\begin{array}{l}\text { Fishing } \\
\text { Area }\end{array}$ & $\begin{array}{l}\text { Vessel } \\
\text { Activity }\end{array}$ & $\begin{array}{l}\text { Acompanied } \\
\text { by }\end{array}$ & $\begin{array}{l}\text { Distance between } \\
\text { encounters }(\mathrm{km})\end{array}$ & $\begin{array}{l}\text { Elapsed } \\
\text { Days }\end{array}$ & $\begin{array}{l}\text { Elapsed } \\
\text { Hours }\end{array}$ & $\begin{array}{l}\text { Min speed } \\
(\mathrm{km} / \mathrm{h})\end{array}$ \\
\hline \multirow[t]{5}{*}{ Sparrow } & \multirow[t]{5}{*}{$\begin{array}{c}\text { scar behind dorsal fin, two little scars close } \\
\text { to the blow hole and fluke }\end{array}$} & $\begin{array}{c}7 / 8 / 200 \\
7\end{array}$ & 44 & $17: 00$ & $\begin{array}{l}\text { Playa } \\
\text { Nueva }\end{array}$ & $\mathrm{H}$ & $\begin{array}{l}\text { Breixo, } \\
\text { Scratchy }\end{array}$ & - & & & \\
\hline & & $\begin{array}{c}10 / 8 / 20 \\
07\end{array}$ & 48 & $10: 45$ & $\begin{array}{l}\text { Playa } \\
\text { Nueva }\end{array}$ & $\mathrm{H}$ & Neboa, Breixo & 5 & 2.74 & 65.75 & 0.08 \\
\hline & & $\begin{array}{c}14 / 08 / 2 \\
007\end{array}$ & 55 & 9:00 & $\begin{array}{l}\text { Playa } \\
\text { Nueva }\end{array}$ & $\mathrm{H}$ & Scratchy & 9 & 3.93 & 94.25 & \\
\hline & & $\begin{array}{c}15 / 08 / 2 \\
007\end{array}$ & 58 & $19: 30$ & $\begin{array}{l}\text { Playa } \\
\text { Nueva }\end{array}$ & $\mathrm{H}$ & & 58 & 1.44 & 34.50 & 1.68 \\
\hline & & $\begin{array}{c}11 / 9 / 20 \\
07\end{array}$ & 125 & $18: 00$ & $\begin{array}{l}\text { Playa } \\
\text { Nueva }\end{array}$ & $\mathrm{P} / \mathrm{S}$ & & 16 & 26.94 & 646.50 & 0.02 \\
\hline \multirow[t]{2}{*}{ Scratchy } & \multirow[t]{2}{*}{ scratch in left lateral } & $\begin{array}{l}7 / 8 / 200 \\
7\end{array}$ & 44 & $17: 00$ & $\begin{array}{l}\text { Playa } \\
\text { Nueva }\end{array}$ & $\mathrm{H}$ & $\begin{array}{l}\text { Sparrow, } \\
\text { Breixo }\end{array}$ & - & & 0.00 & \\
\hline & & $\begin{array}{c}14 / 08 / 2 \\
007\end{array}$ & 55 & 9:00 & $\begin{array}{l}\text { Playa } \\
\text { Nueva }\end{array}$ & $\mathrm{H}$ & Sparrow & 4 & 6.67 & 160.00 & 0.03 \\
\hline \multirow[t]{5}{*}{ Breixo } & \multirow[t]{5}{*}{ right lateral scar, snout scar and fluke } & $\begin{array}{l}7 / 8 / 200 \\
7\end{array}$ & 44 & $17: 00$ & $\begin{array}{l}\text { Playa } \\
\text { Nueva }\end{array}$ & $\mathrm{H}$ & $\begin{array}{l}\text { Sparrow, } \\
\text { Scratchy }\end{array}$ & - & & 0.00 & \\
\hline & & $\begin{array}{c}10 / 8 / 20 \\
07\end{array}$ & 48 & $10: 45$ & $\begin{array}{l}\text { Playa } \\
\text { Nueva }\end{array}$ & $\mathrm{H}$ & $\begin{array}{l}\text { Neboa, } \\
\text { Sparrow }\end{array}$ & 5 & 2.74 & 65.75 & 0.08 \\
\hline & & $\begin{array}{c}14 / 08 / 2 \\
007\end{array}$ & 56 & 9:45 & $\begin{array}{l}\text { Playa } \\
\text { Nueva }\end{array}$ & $\mathrm{P} / \mathrm{S}$ & & 7 & 3.96 & 95.00 & 0.07 \\
\hline & & $\begin{array}{c}14 / 08 / 2 \\
007\end{array}$ & 56 & $11: 00$ & $\begin{array}{l}\text { Playa } \\
\text { Nueva }\end{array}$ & $T$ & Neboa & 13 & 0.05 & 1.25 & 10.40 \\
\hline & & $\begin{array}{c}27 / 08 / 2 \\
007\end{array}$ & 86 & $10: 15$ & $\begin{array}{l}\text { Carson } \\
\text { Canyon }\end{array}$ & $\mathrm{P} / \mathrm{S}$ & Faneca, Ibo & 235 & 12.97 & 311.25 & 0.76 \\
\hline \multirow[t]{8}{*}{ Neboa } & \multirow[t]{8}{*}{ scars in both laterals and fluke } & $\begin{array}{c}8 / 8 / 200 \\
7\end{array}$ & 45 & $18: 15$ & $\begin{array}{l}\text { Playa } \\
\text { Nueva }\end{array}$ & $\mathrm{H}$ & & - & & 0.00 & \\
\hline & & $\begin{array}{c}8 / 8 / 200 \\
7\end{array}$ & 46 & $20: 15$ & $\begin{array}{l}\text { Playa } \\
\text { Nueva }\end{array}$ & $\mathrm{T}$ & & 8 & 0.08 & 2.00 & 4.00 \\
\hline & & $\begin{array}{c}10 / 8 / 20 \\
07\end{array}$ & 48 & $10: 45$ & $\begin{array}{l}\text { Playa } \\
\text { Nueva }\end{array}$ & $\mathrm{H}$ & $\begin{array}{l}\text { Breixo, } \\
\text { Sparrow }\end{array}$ & 113 & 1.60 & 38.50 & 2.94 \\
\hline & & $\begin{array}{c}10 / 8 / 20 \\
07\end{array}$ & 49 & $22: 00$ & $\begin{array}{l}\text { Playa } \\
\text { Nueva }\end{array}$ & $\mathrm{H}$ & & 1 & 0.47 & 11.25 & 0.09 \\
\hline & & $\begin{array}{c}13 / 08 / 2 \\
007\end{array}$ & 54 & $18: 15$ & $\begin{array}{l}\text { Playa } \\
\text { Nueva }\end{array}$ & $\mathrm{T}$ & & 57 & 2.84 & 68.25 & 0.84 \\
\hline & & $\begin{array}{c}14 / 08 / 2 \\
007\end{array}$ & 56 & $11: 00$ & $\begin{array}{l}\text { Playa } \\
\text { Nueva }\end{array}$ & $\mathrm{T}$ & Breixo & 50 & 0.70 & 16.75 & 2.99 \\
\hline & & $\begin{array}{c}14 / 08 / 2 \\
007\end{array}$ & 56 & $18: 15$ & $\begin{array}{l}\text { Playa } \\
\text { Nueva }\end{array}$ & $\mathrm{T}$ & & 36 & 0.30 & 7.25 & 4.97 \\
\hline & & $\begin{array}{c}14 / 08 / 2 \\
007\end{array}$ & 56 & $21: 00$ & $\begin{array}{l}\text { Playa } \\
\text { Nueva }\end{array}$ & $\mathrm{H}$ & & 12 & 0.11 & 2.75 & 4.36 \\
\hline
\end{tabular}




\begin{tabular}{|c|c|c|c|c|c|c|c|c|c|c|c|}
\hline \multirow[t]{5}{*}{ Faneca } & \multirow[t]{5}{*}{ left lateral scar, fluke } & $\begin{array}{c}27 / 08 / 2 \\
007\end{array}$ & 86 & $10: 15$ & $\begin{array}{l}\text { Carson } \\
\text { Canyon }\end{array}$ & $\mathrm{P} / \mathrm{S}$ & Breixo, Ibo & - & & 0.00 & \\
\hline & & $\begin{array}{c}28 / 08 / 2 \\
007\end{array}$ & 88 & 21:05 & $\begin{array}{l}\text { Carson } \\
\text { Canyon }\end{array}$ & $\mathrm{H}$ & & 59 & 1.45 & 34.83 & 1.69 \\
\hline & & $\begin{array}{l}29 / 08 / 2 \\
007\end{array}$ & 90 & $9: 30$ & $\begin{array}{l}\text { Carson } \\
\text { Canyon }\end{array}$ & $\mathrm{T}$ & & 54 & 0.52 & 12.42 & 4.35 \\
\hline & & $\begin{array}{l}29 / 08 / 2 \\
007\end{array}$ & 90 & $14: 45$ & $\begin{array}{l}\text { Carson } \\
\text { Canyon }\end{array}$ & $\mathrm{T}$ & & 31 & 0.22 & 5.25 & 5.90 \\
\hline & & $\begin{array}{l}29 / 08 / 2 \\
007\end{array}$ & 91 & $21: 15$ & $\begin{array}{l}\text { Carson } \\
\text { Canyon }\end{array}$ & $T$ & & 5 & 0.27 & 6.50 & 0.77 \\
\hline \multirow[t]{2}{*}{ Ibo } & \multirow[t]{2}{*}{$\begin{array}{l}\text { scar in dorsal fin and three little depressions } \\
\text { in the surface of the head }\end{array}$} & $\begin{array}{l}27 / 08 / 2 \\
007\end{array}$ & 86 & $10: 15$ & $\begin{array}{l}\text { Carson } \\
\text { Canyon }\end{array}$ & $\mathrm{P} / \mathrm{S}$ & $\begin{array}{l}\text { Faneca, } \\
\text { Breixo }\end{array}$ & - & & 0.00 & \\
\hline & & $\begin{array}{l}9 / 9 / 200 \\
7\end{array}$ & 121 & $16: 30$ & $\begin{array}{l}\text { Playa } \\
\text { Nueva }\end{array}$ & $\mathrm{H}$ & & 276 & 13.26 & 318.25 & 0.87 \\
\hline Marmu & fluke & $\begin{array}{l}8 / 8 / 200 \\
7\end{array}$ & 45 & $13: 23$ & $\begin{array}{l}\text { Playa } \\
\text { Nueva }\end{array}$ & $\mathrm{T}$ & & - & & & \\
\hline Tor & scar in blow hole & $\begin{array}{l}29 / 07 / 2 \\
007\end{array}$ & 25 & $11: 10$ & $\begin{array}{l}\text { Playa } \\
\text { Nueva }\end{array}$ & $\mathrm{H}$ & & - & & & \\
\hline Nat & fluke & $\begin{array}{l}28 / 07 / 2 \\
007\end{array}$ & 23 & $10: 44$ & $\begin{array}{l}\text { Playa } \\
\text { Nueva }\end{array}$ & $\mathrm{H}$ & & - & & & \\
\hline Noah & scar in left lateral and fluke & $\begin{array}{c}29 / 08 / 2 \\
007\end{array}$ & 91 & $21: 15$ & $\begin{array}{l}\text { Carson } \\
\text { Canyon }\end{array}$ & $\mathrm{T}$ & Faneca & - & & & \\
\hline
\end{tabular}


3. Figures

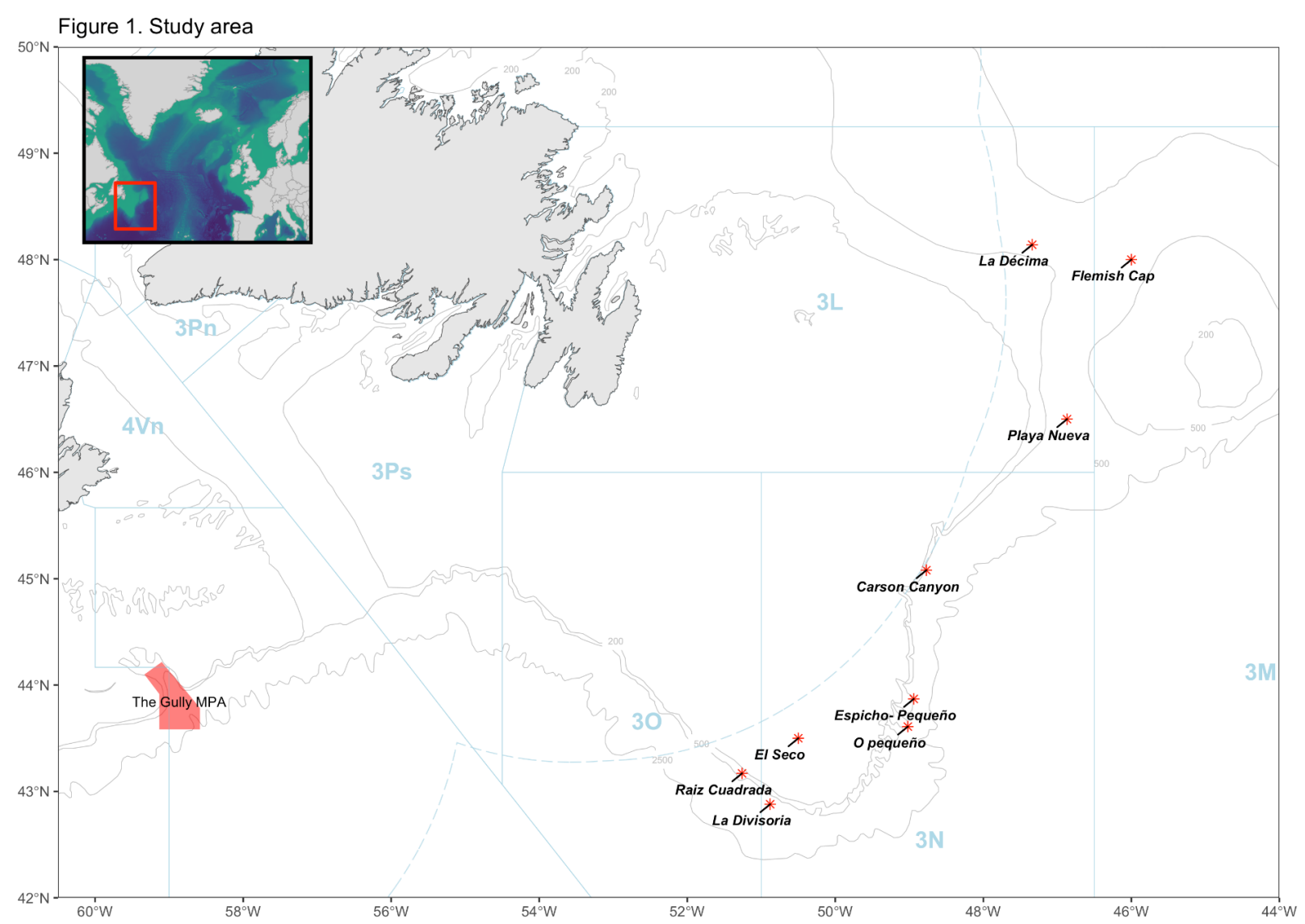

Figure 1. Map of the NAFO convention area, showing NAFO divisions, fishing areas named by fishermen and The Gully marine protected area (MPA). 


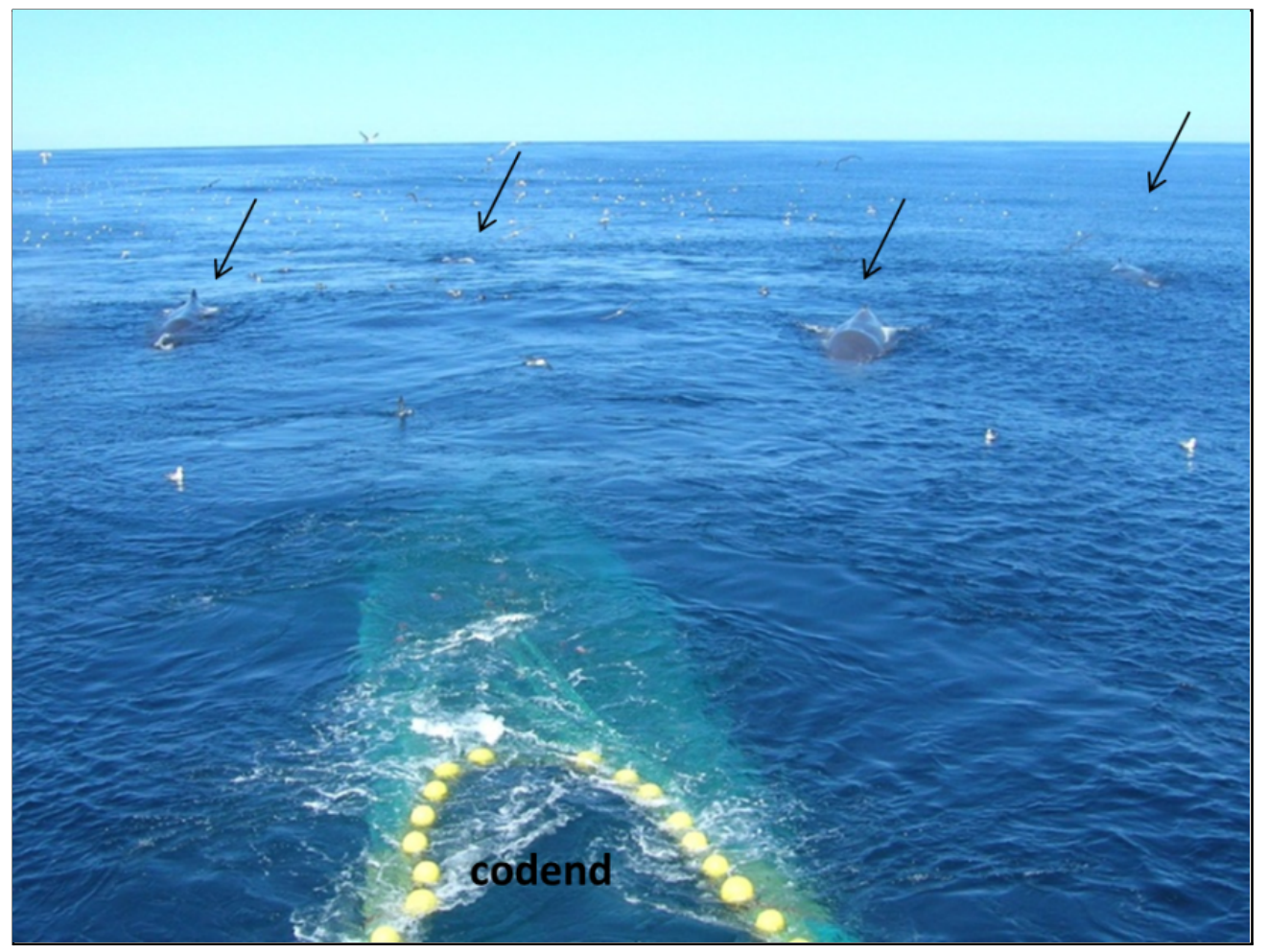

Figure 2. Four sperm whales following the vessel at the end hauling. The codend can be clearly seen at the surface behind the yellow buoys. 

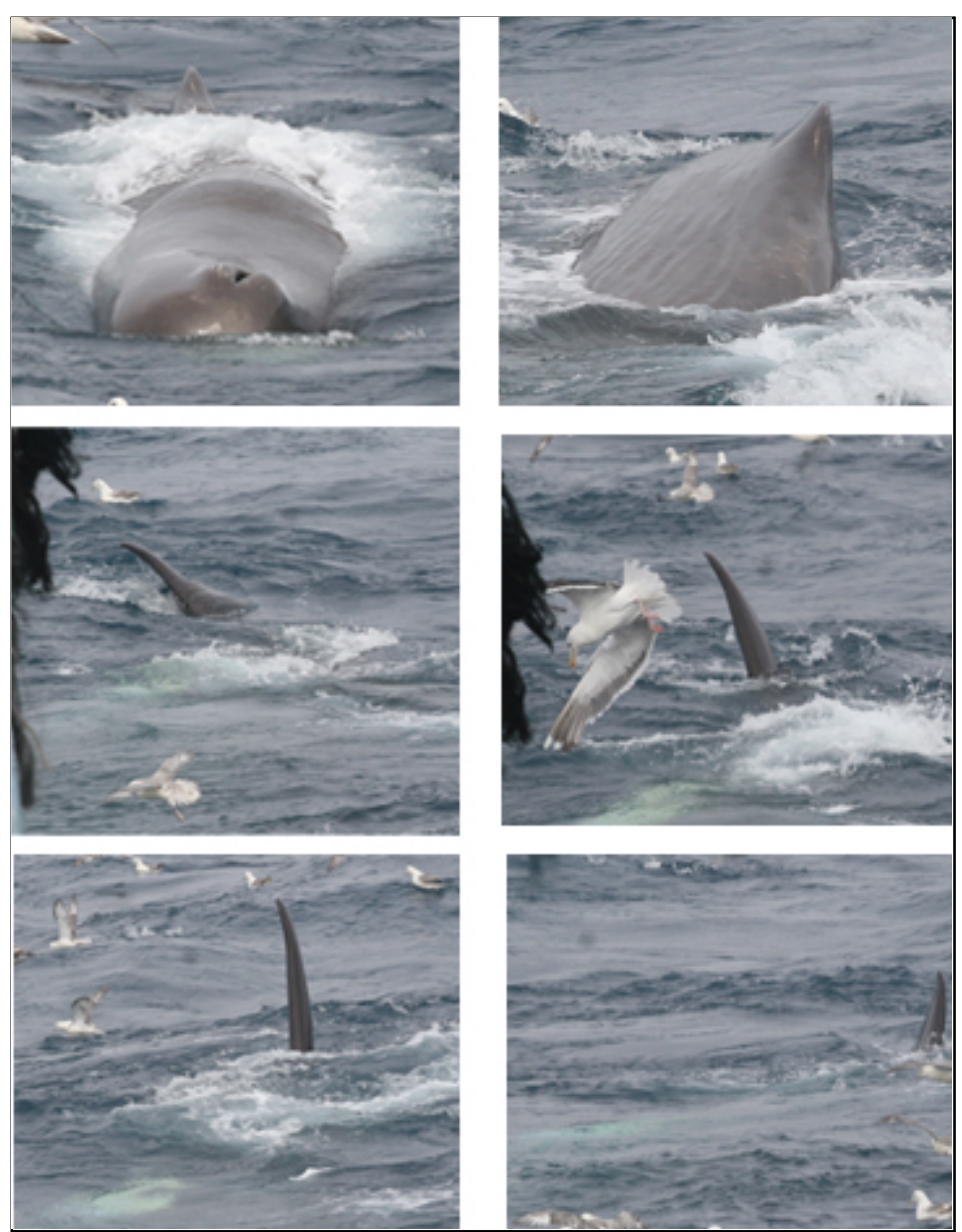

Figure 3. Sequence showing a sperm whale turning his body to the right. First picture showing his blowhole and dorsal fin, second turning to the right, dorsal fin and part of the side is observed, in the last four pictures the fluke is going to the right. In the last picture the sperm whale is almost upside down. We associated this pattern of observations with probable feeding close to the surface. 


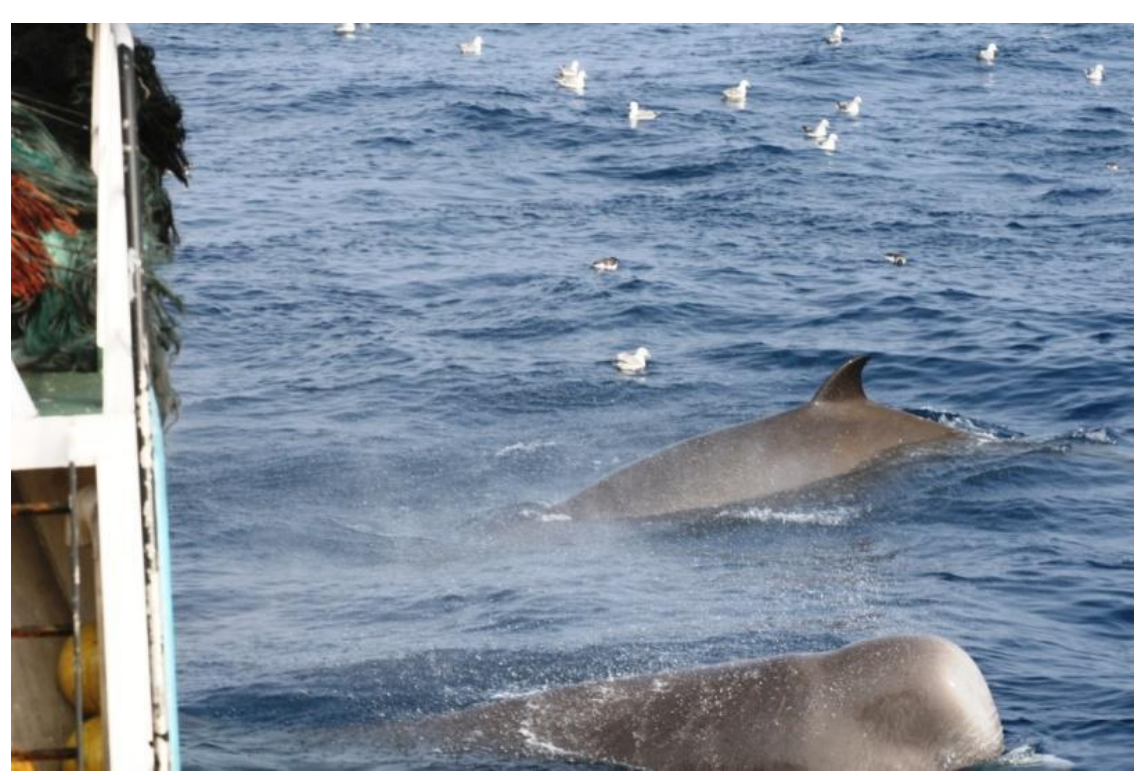

Figure 4. Bottlenose whales close to the boat at the end of hauling. 
Whale Sightings and Fishing effort

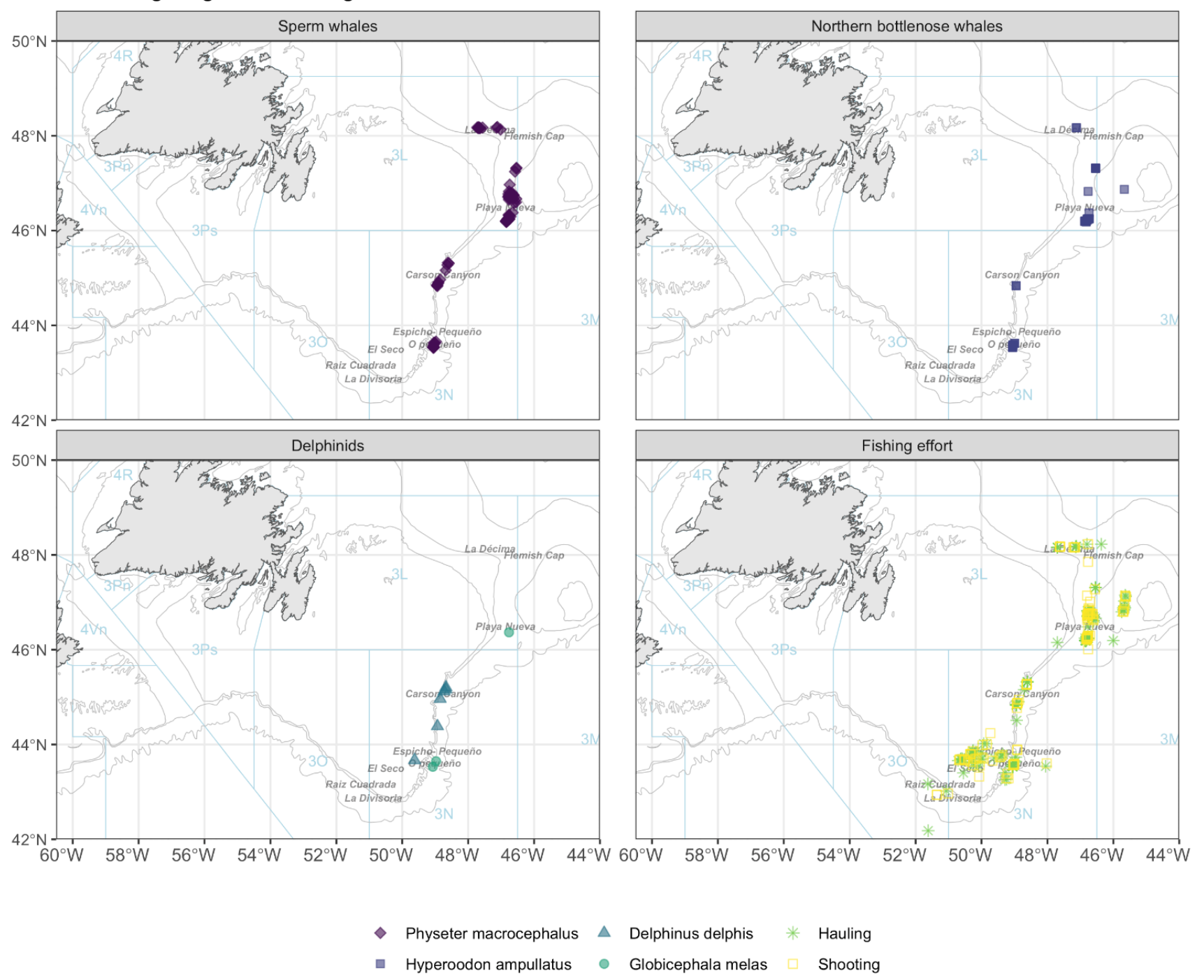

Figure 5. Whale sightings of sperm whales, northern bottlenose whales, delphinids (D. delphis and G. melas) and locations of fishing effort for shooting and hauling. 
A

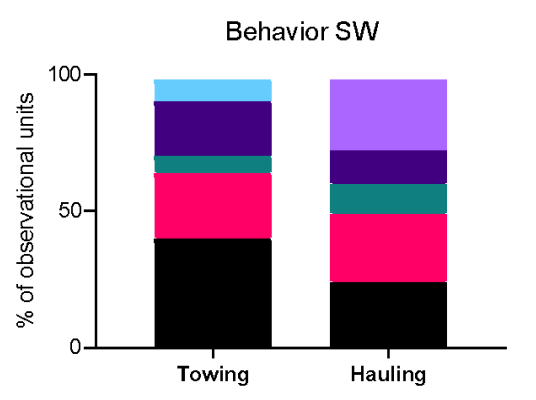

C

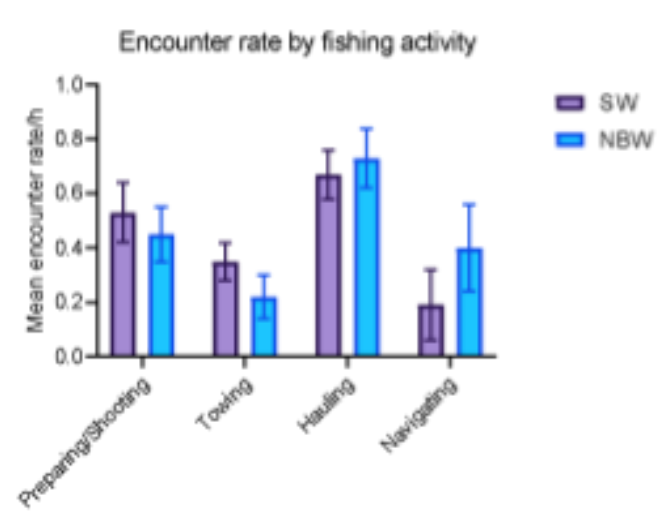

B
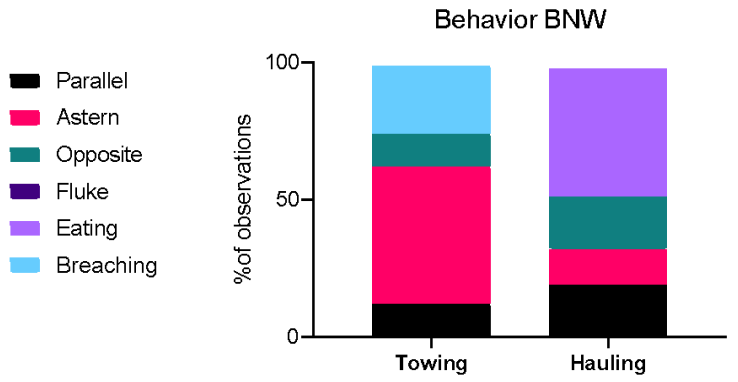

$$
\begin{aligned}
& \text { - Parallel } \\
& \text { - Astern } \\
& \text { Opposite } \\
& \text { - Fluke } \\
& \text { Eating } \\
& \text { Breaching }
\end{aligned}
$$

D

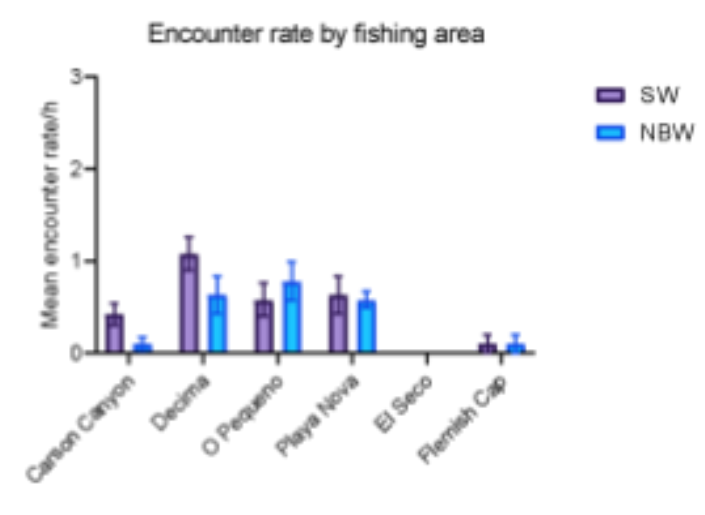

Figure 6. Whale behaviours by observational unit, fishing area and fishing activity. (A) Sperm whales (B) Nothern bottlenose whales' behavior per fishing activity. Mean whale encounter rates per (C) fishing activity and (D) fishing area. Six behaviors were scored: (1) swimming parallel to the vessel, (2) following the vessel at a constant speed and near constant distance astern, (3) swimming in the opposite direction from the vessel (normally within $50 \mathrm{~m}$ ) (4) fluke, (5) probable feeding and (6) Breaching/lobtailing. 


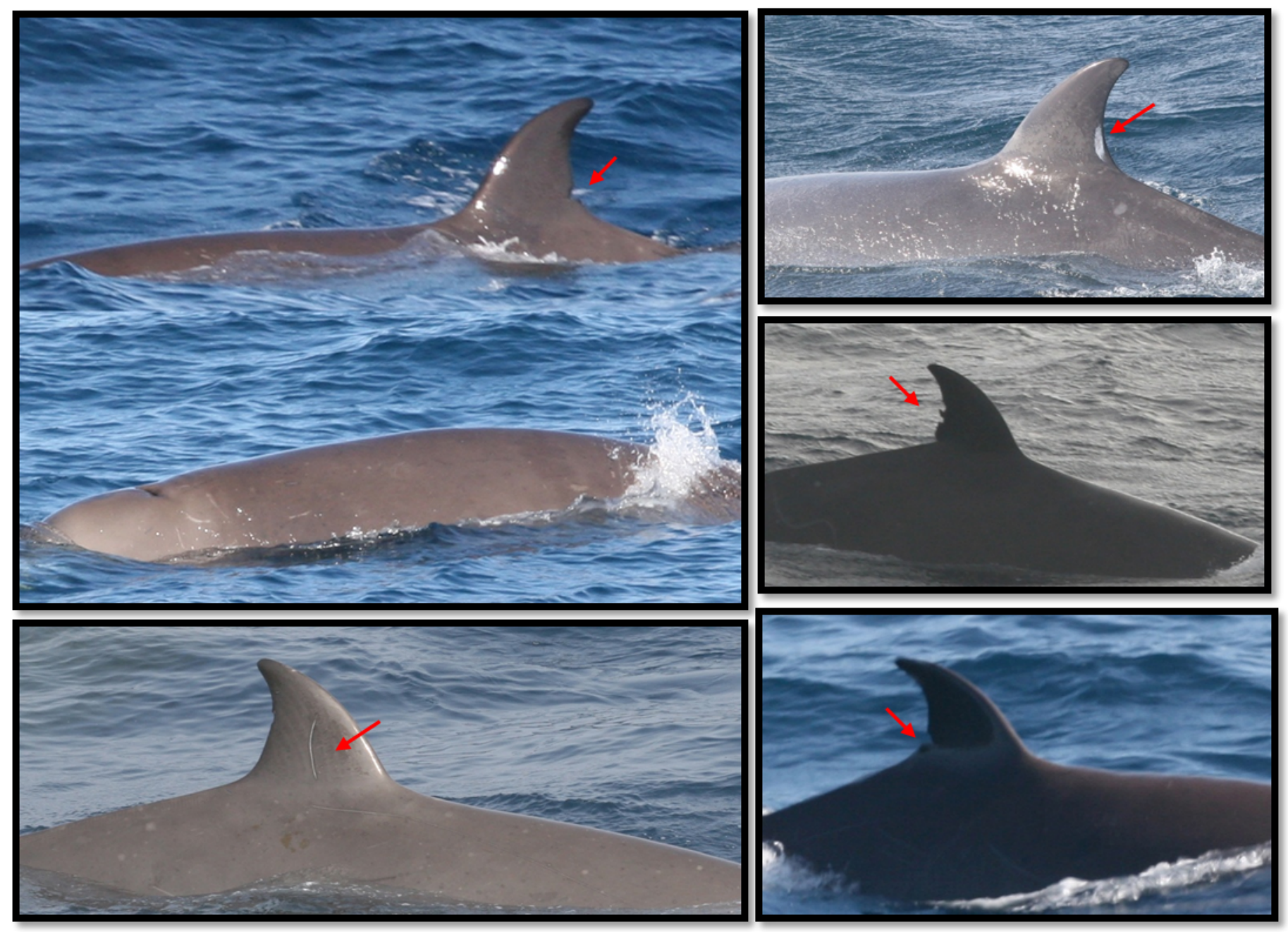

Figure 7. Examples of distinct marks used for bottlenose whale identification, including notches and large fin scars. 

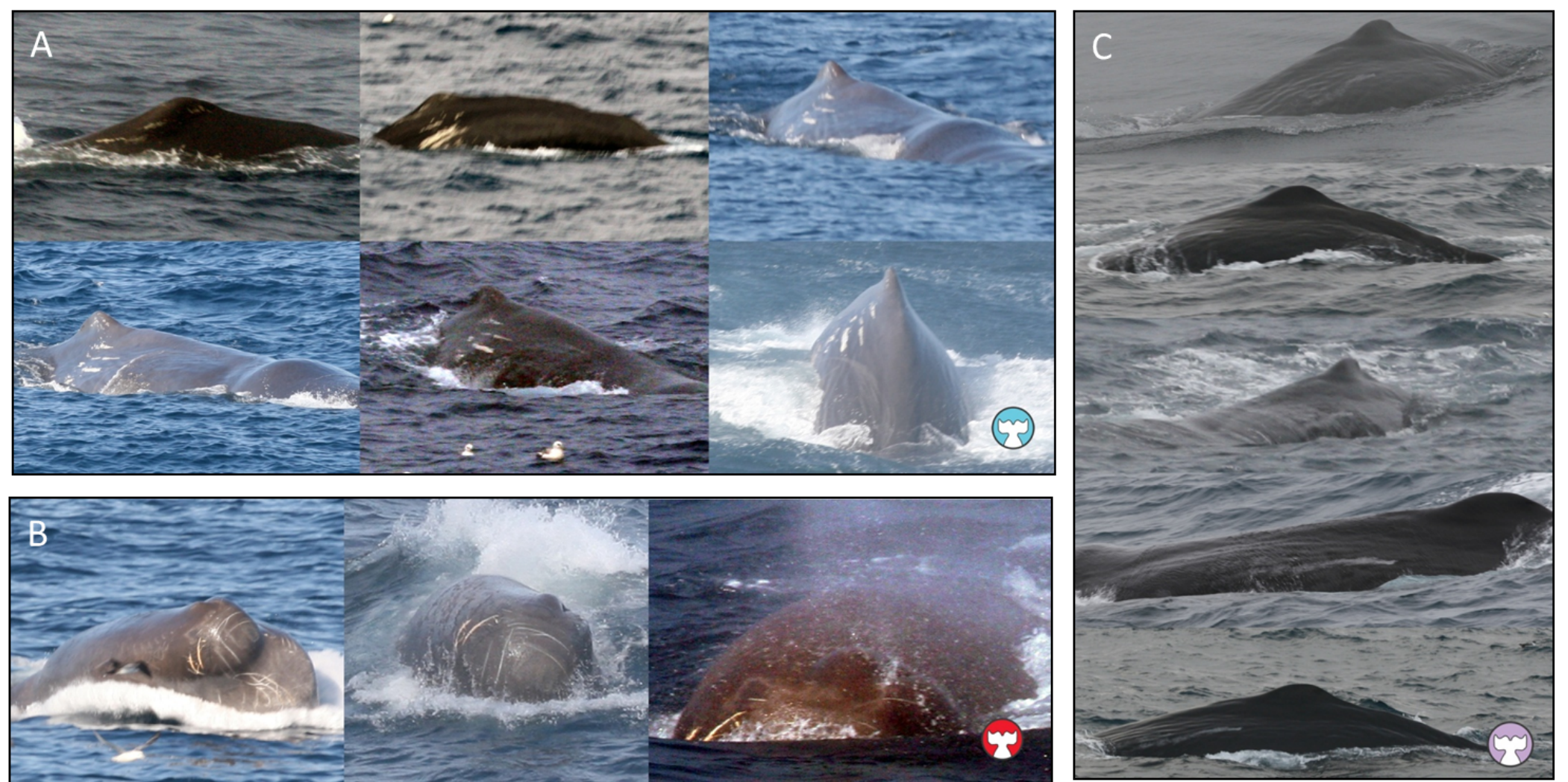

Figure 8. Examples of distinct marks used for sperm whale identification (A) Neboa, with characteristic scars at both sides of the dorsal fin (B) Breixo, showed many scars in the front part of his head (C) Faneca, a lateral scar visible only from the left side, but very easy to identify. 
bioRxiv preprint doi: https://doi.org/10.1101/2021.10.25.464263; this version posted October 26, 2021. The copyright holder for this preprint (which was not certified by peer review) is the author/funder, who has granted bioRxiv a license to display the preprint in perpetuity. It is made available under aCC-BY 4.0 International license.

A

B
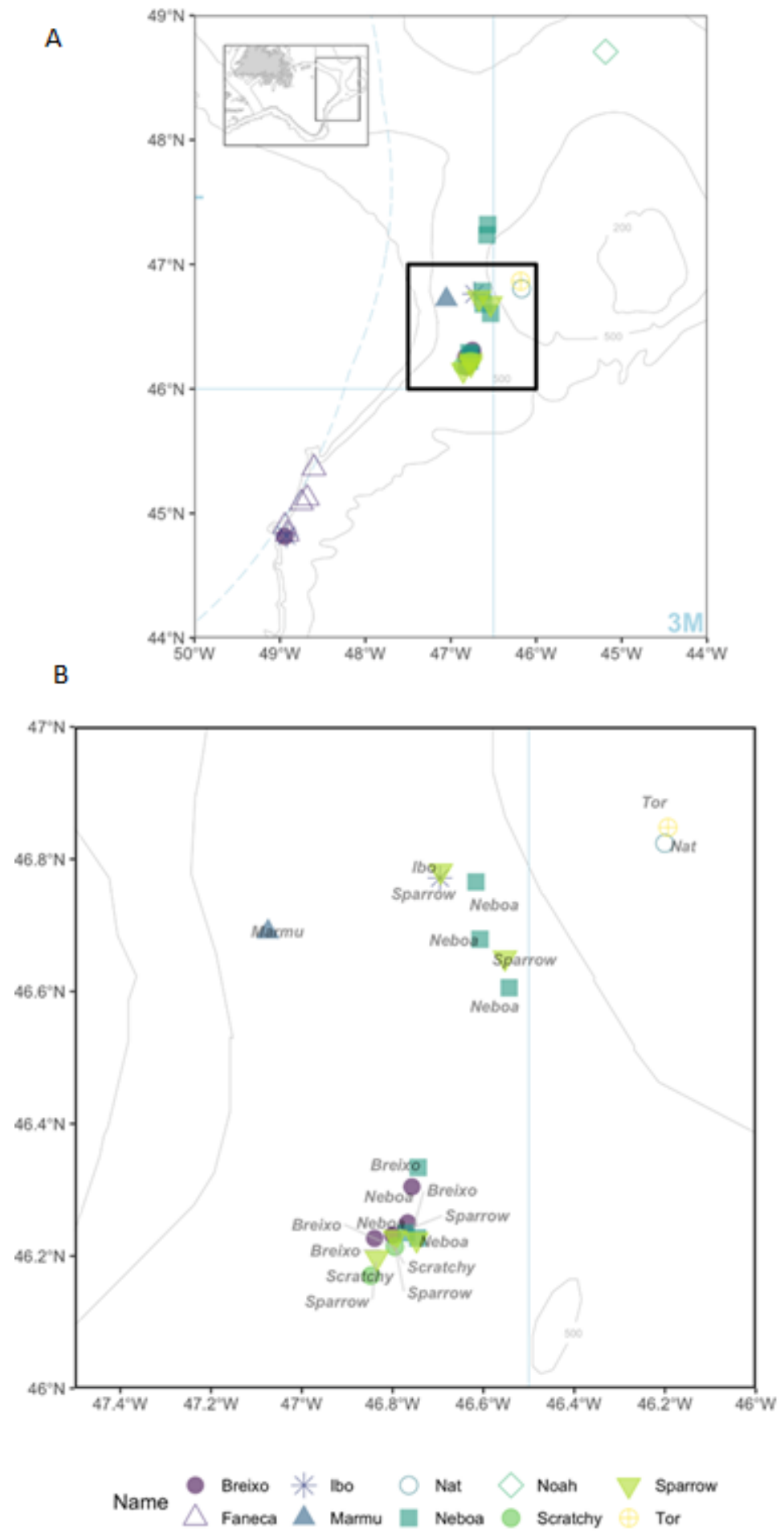

Figure 9. Location of sightings of individual sperm whales in (A) the entire study area and (B) an inset of concentrated sightings in the Flemish Pass. 


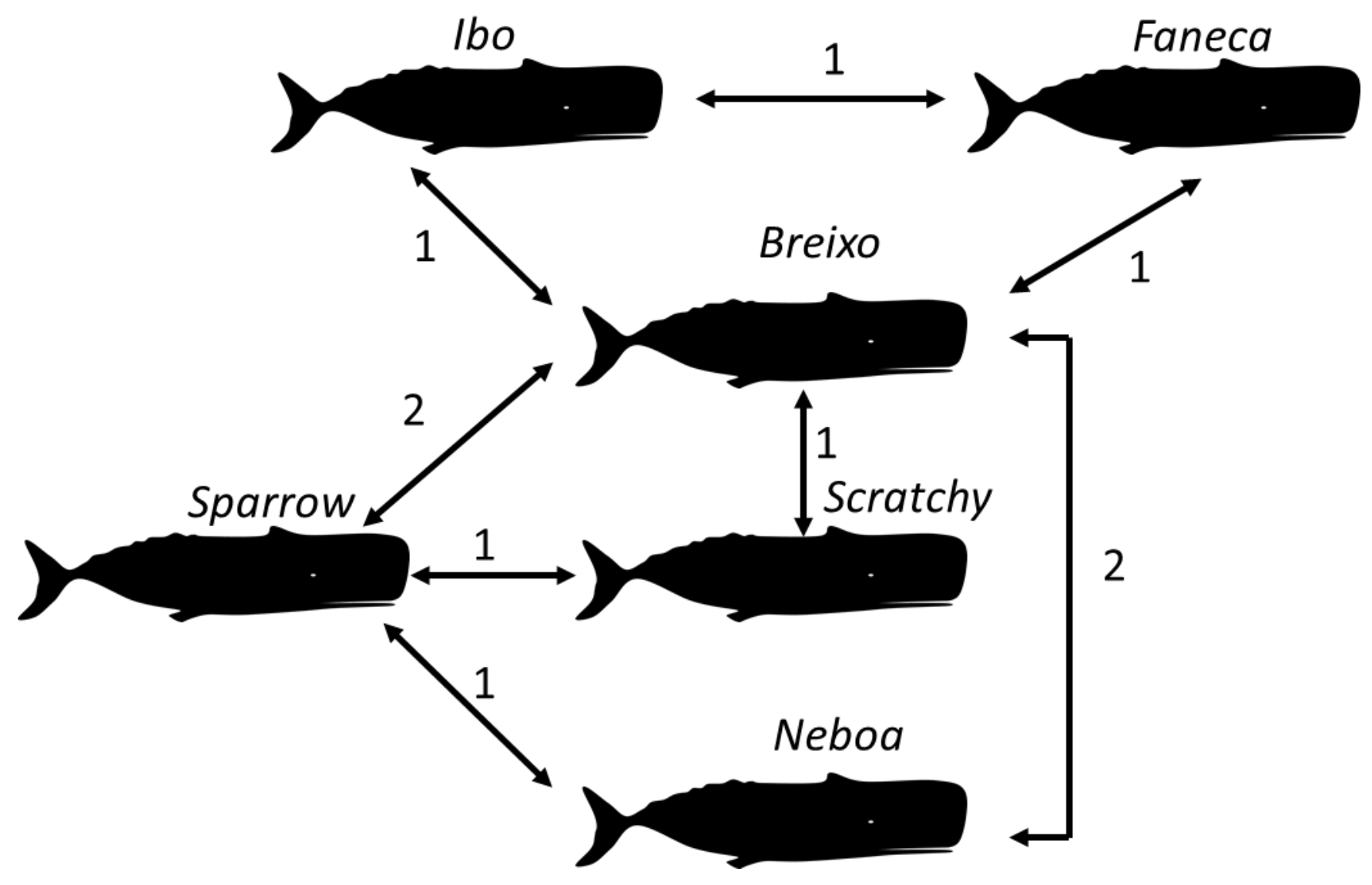

Figure 10. Associations between identified sperm whales. The arrows show the presence of both individuals together close to the vessel, and the number expresses times the whales were seen together. Breixo in the middle was seen with all the other animals. 